\title{
HOUSTON HEARTS: A HISTORY OF CARDIOVASCULAR SURGERY AND MEDICINE AT HOUSTON METHODIST DEBAKEY HEART \& VASCULAR CENTER
}

From the Michael E. DeBakey, M.D., Distinguished Lectureship Series, presented by William L. Winters, Jr., M.D., Editor, Methodist DeBakey Cardiovascular Journal, on January 19, 2015

Houston Methodist DeBakey Heart \& Vascular Center, Houston Methodist Hospital, Houston, Texas

\section{Introduction}

This is a singular honor for me to present the seventh Michael E. DeBakey Lecture. When I was asked to do so, it was suggested I might discuss Houston Hearts: A History of Cardiovascular Surgery and Medicine and The Methodist DeBakey Heart $\mathcal{E}$ Vascular Center published earlier this year (Photo 1). So I present to you

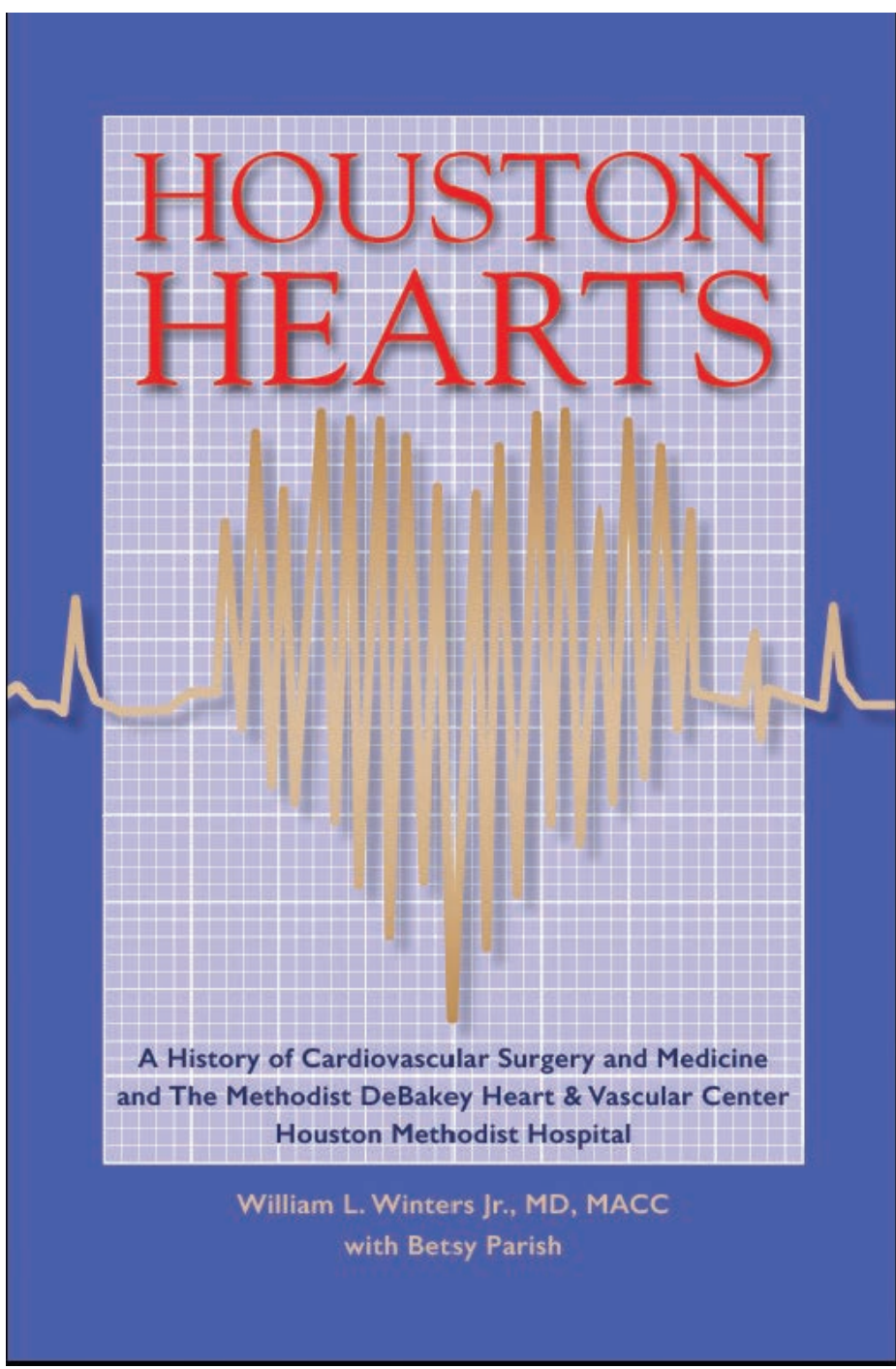

Photo 1. Book cover for Houston Hearts: A History of Cardiovascular Surgery and Medicine and The Methodist DeBakey Heart \& Vascular Center, which was published in early 2015. highlights from this narrative that was dedicated to Dr. Michael E. DeBakey. To set the stage, I have included my favorite picture of Dr. DeBakey taken on Doctor's Day, 1999 (Photo 2). Dr. DeBakey had a well-developed sense of humor. The idea of writing this book germinated in 1968 when I moved to Houston and came to appreciate who I was working with. While this history mirrors much that took place worldwide, many of the innovations and first-of-a-kind events originated with Dr. DeBakey and others right here at Houston Methodist Hospital. The surgeons-DeBakey, Crawford, Cooley, Morris, Beall, Noon, Howell—already were becoming legendary, as were the cardiologists: Gotto, Entman, Roberts, Verani, Beazley. Don W. Chapman, to my knowledge, was the first academically-trained cardiologist at Baylor College of Medicine and Methodist, and he subsequently became a teaching legend at Baylor. He was the one who invited me to Houston in 1968 to join his practice, the Chapman Group.

In 1953, when I graduated from Northwestern Medical School, those who survived a heart attack were treated with 6 weeks of bed rest. Drug choices were limited. In 1960, when I took my Medicine board, I was given the option of interpreting ballistocardiograms or electrocardiograms. My cardiology fellowship lasted 1 year, during which time I spent long hours with Bill Wright, a surgical resident, learning to run a heartlung machine doing sham operations on dogs. Not a single dog survived, but after a year we were deemed sufficiently trained to

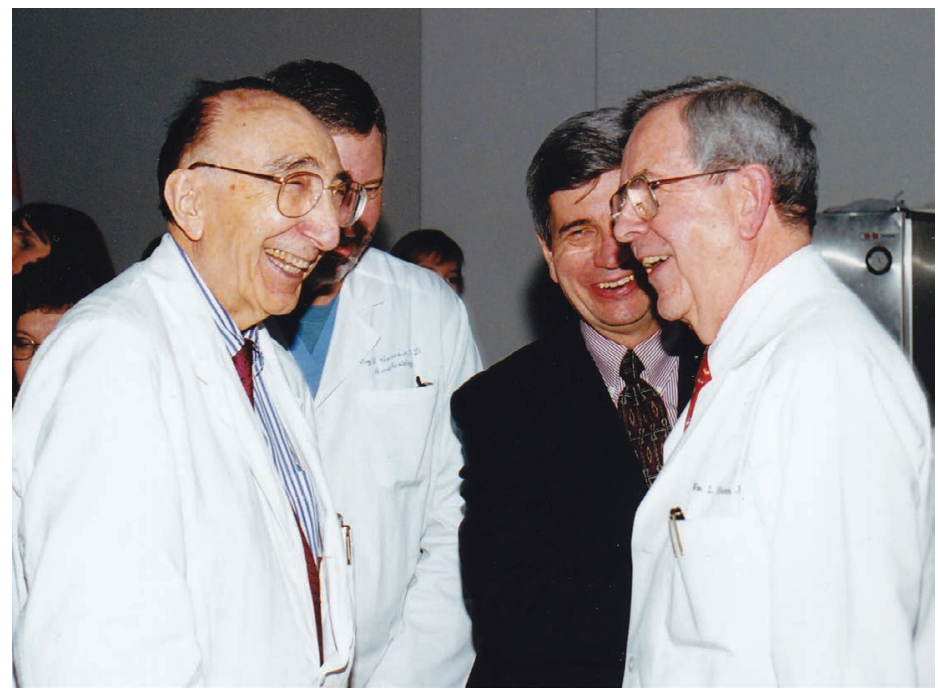

Photo 2. Michael E. DeBakey attends Doctor's Day celebration with William Winters at The Methodist Hospital in 1999. 
begin working on live patients. So in 1958, Bill and I ran the heartlung machine for Temple University Hospital's first open-heart operation, performed by our two thoracic surgeons. The patient was a young boy with a ventricular septal defect. Happily, the patient, surgeons, and heart-lung operators all survived.

Don Chapman had many similar experiences. In the 40 years we worked together, we reminisced often about the extraordinary events taking place during our careers, especially at Houston Methodist Hospital, and he encouraged me to record some of this history. So 10 years ago, I began doing video interviews with people who had long tenures, starting with Chapman. Initially, the interviews were just with the cardiovascular faculty, but they later embraced other specialties. To date, there are 70 video interviews, all available in the Houston Methodist Hospital library.

Five years ago, with the blessings of Houston Methodist Hospital's then-CEO Ron Girotto, I made a decision to write the cardiovascular history of this institution. I knew Betsy Parish, a former Houston Post writer and author of Legacy, A History of Texas Children's Hospital, and inquired if she would be interested in collaborating. For those of you who have read our book, the easy readability is Betsy's accomplishment. She is also responsible for capturing many of the national exploits of Dr. DeBakey from her scouring of the Texas Medical Center Library archives. We scrupulously referenced everything from the library archives, medical publications, lay press, my interviews, interviews by Betsy, and my personal knowledge. We sent selected chapters to various principals for accuracy. The book was subsequently reviewed by several Houston Methodist Hospital board members, legal counsel, and officers; former CEOs Larry Mathis and Ron Girotto; Drs. George Noon, Tony Gotto, and several prominent national journal editors, and former hospital staff.

The book conveniently divides the history into three phases. The early chapters describe the origins of Houston Methodist Hospital, beginning in 1908 with the establishment of the Norsworthy Hospital, later renamed The Methodist Hospital; its subsequent growing pains and relocation to the Texas Medical Center; the development of the Texas Medical Center, the early years of Michael DeBakey; and the move of Baylor University College of Medicine from Dallas to Houston.

The second phase covers three decades when cardiovascular surgery came of age, beginning with the arrival of Don Chapman in 1944 and Michael DeBakey in 1948. In those days, the cardiovascular surgeons, led by DeBakey and his colleagues, were the innovators and the doers while cardiologists were primarily the support team. Treatment of hypertension, coronary artery disease, and heart failure was still primitive compared to what is available today.

The third phase ushers in the 1970s, when the era of interventional cardiology began to take shape. Dr. Henry McIntosh arrived from Duke University as chairman of the Department of Medicine at both Baylor and Methodist, where he established the cardiology section and began Methodist's first cardiology training program. He was followed in 1977 by Dr. Gotto, who in turn recruited Dr. Richard Miller as the first chief of cardiology. During this time, a report delivered at the annual American Heart Association meeting in November of 1978 turned the cardiology community on its ear and transformed cardiologists from diagnosticians into interventionalists. Andreas Gruentzig, a German radiologist working at the University of Zurich, reported his studies using a balloon catheter to open arteries partially obstructed by atherosclerosis. So was born coronary angioplasty.

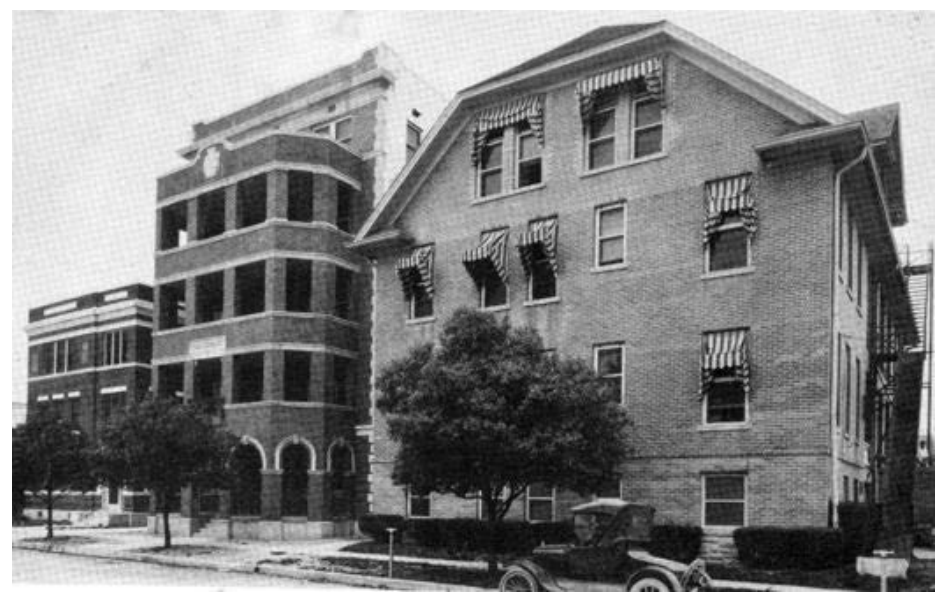

Photo 3. The two buildings comprising the original Methodist Hospital, circa 1924.

\section{Phase I: Beginnings}

The story of Houston Methodist Hospital began in 1908 when a general surgeon, Dr. Oscar (Laertius) Norsworthy, built a fourstory hospital on Rosalie Avenue in downtown Houston. In 1919, he offered the hospital to the Texas Conference of the Methodist Episcopal Church on the condition that they build another building on adjacent property that he also owned. His offer was accepted, and in 1924 the two buildings became known as The Methodist Hospital (Photo 3). Josie Roberts, a young widow, was hired to serve as business manager and was appointed as the hospital's administrator in 1931 (Photo 4).

The hospital's Board of Trustees was originally created in 1919 and included Walter Fondren, one of the founders of Humble Oil. The Fondrens played a crucial role in the planning and financing of the hospital until Walter Fondren died abruptly in January of 1939, at which time Mrs. Fondren assumed the mantle (Photo 5). Thereafter, she and Josie Roberts were the lynchpins in the further development of the hospital.

In May, 1942, the MD Anderson Board of Trustees reported plans to develop a medical center on land near Hermann Hospital, a plan endorsed in 1943 by Houston voters. Two years later, the MD Anderson board made an offer of land to The Methodist Hospital. Not enthralled with the location, the two women

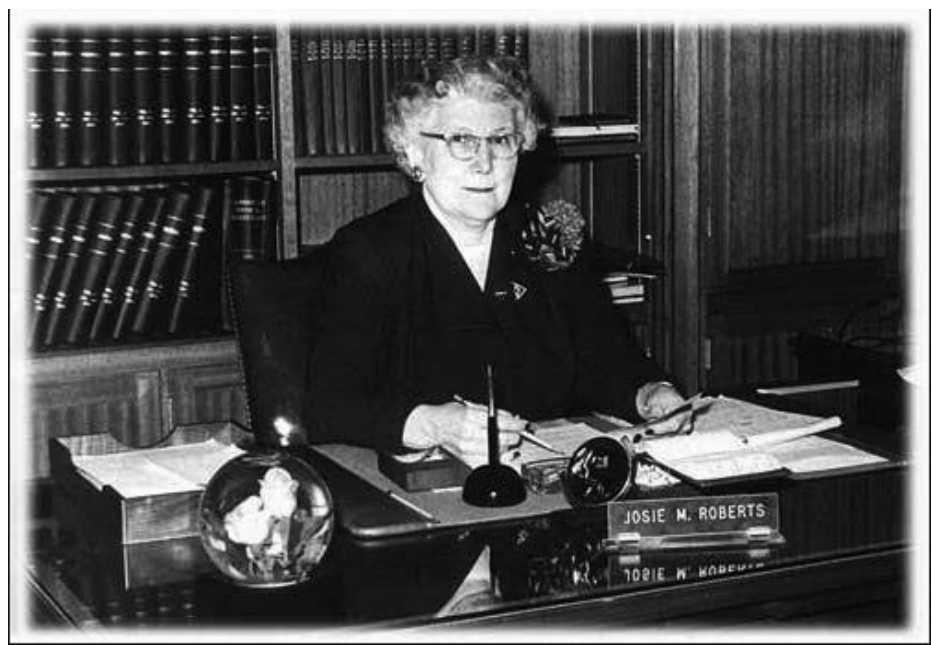

Photo 4. Josie Roberts, first administrator of The Methodist Hospital, circa 1931 


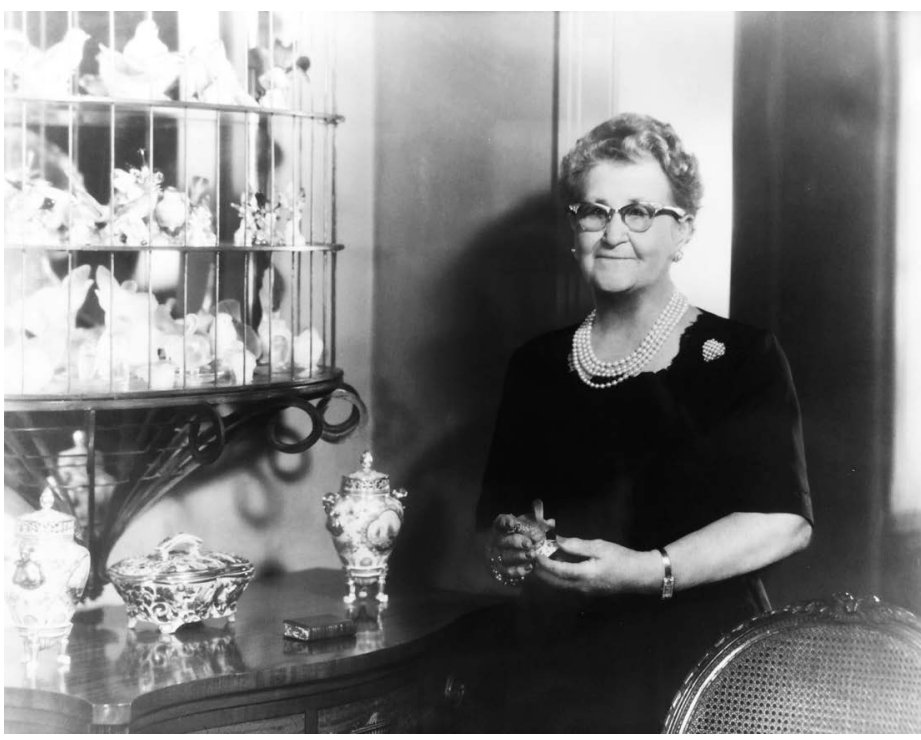

Photo 5. Board member Ella Fondren was responsible for the hospital's original development and expansion, circa 1939.

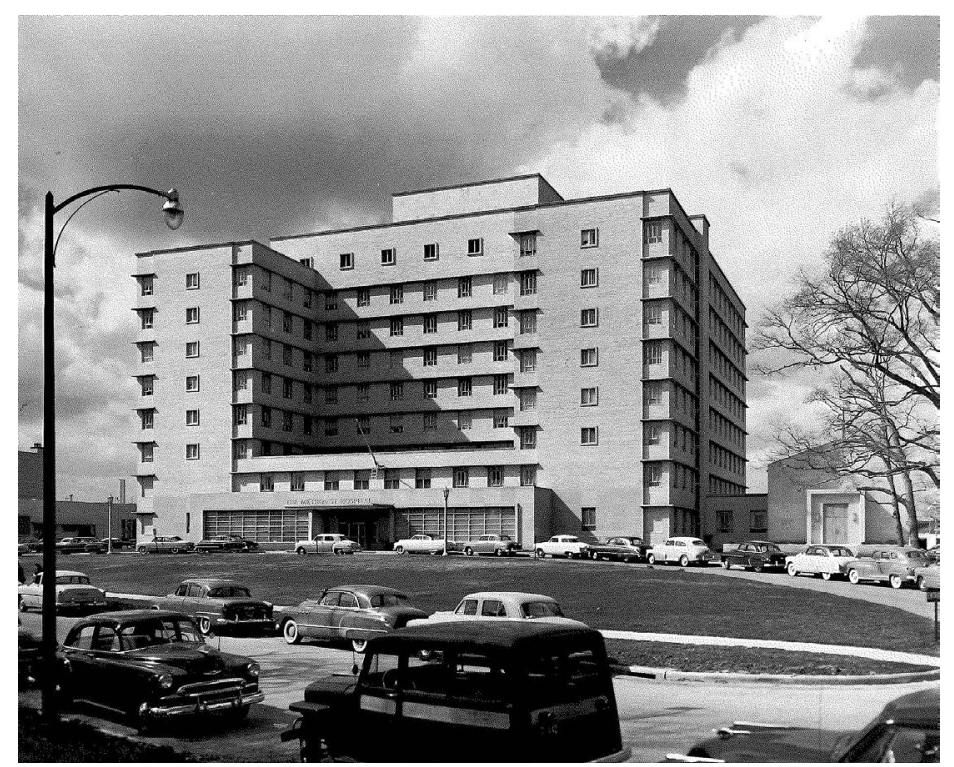

Photo 6. The new Methodist Hospital located on old Main Street, circa 1951

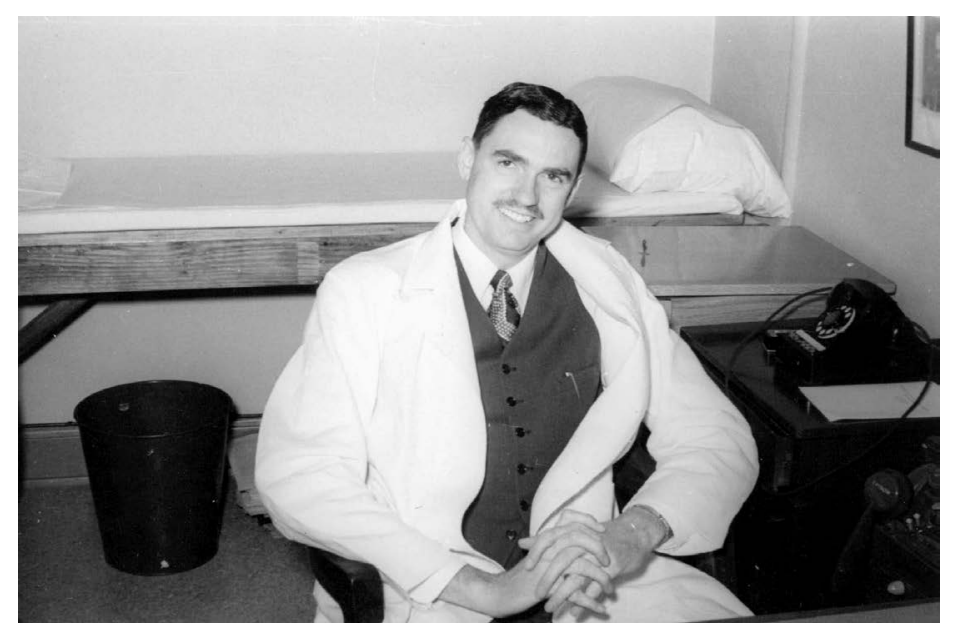

Photo 7. Don Chapman, M.D., circa 1944.

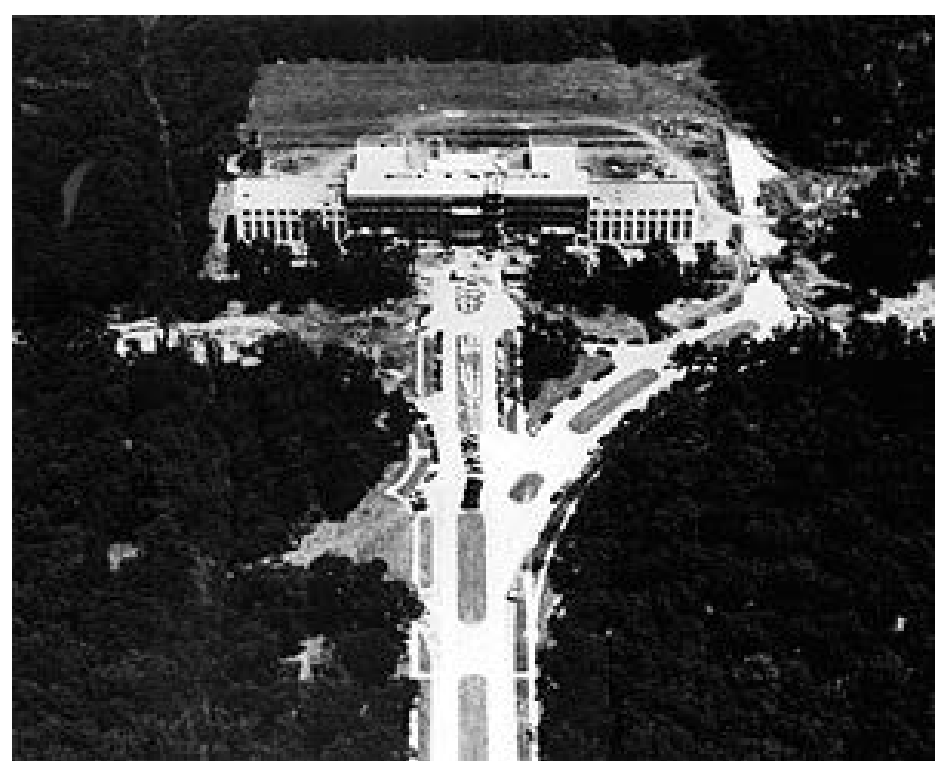

Photo 8. Aerial view of the Baylor University College of Medicine, circa 1947.

collaborated with Dr. Ernst W. Bertner, then president of the Texas Medical Center, and selected a parcel of land between Bertner and Fannin streets. As expansion plans progressed, Ted Bowen, a graduate of the Washington University School of Hospital Administration in St. Louis, was hired in 1948 to assist Josie Roberts. The cornerstone for the new Methodist Hospital was laid in 1949. On November 10, 1951, it opened for business (Photo 6). Newspapers reported it as the "most modern hospital in the South." By 1953, Josie Roberts retired, satisfied with the new construction and operation, and Ted Bowen took the helm.

During the years between 1939 and 1948, a number of important events occurred in the Texas Medical Center.

1939: The MD Anderson Foundation was established.

1943: The MD Anderson Foundation and Baylor University College of Medicine in Dallas signed an agreement to bring the medical school to Houston. The first classes were held that year in a converted Sears warehouse on Buffalo Drive.

1944: Don Chapman arrived at Baylor (Photo 7) and began doing heart catheterizations at Hermann Hospital with the "Dawn Patrol," so named because they had access to their primitive cath lab in radiology only in the wee hours of the mornings.

1945: The Texas Medical Center was chartered as a nonprofit corporation.

1947: The Hugh Roy and Lillie Cullen Foundation was endowed. Also that year, the new Baylor University College of Medicine building opened, named for the Cullens (Photo 8).

1948: The Fondren Foundation was established in honor of Walter W. Fondren. Both the Cullen and Fondren foundations played important roles in the growth of The Methodist Hospital.

\section{A New Surgeon Transforms Cardiovascular Surgery}

In the preceding decade, a promising young surgeon named Michael E. DeBakey (Photo 9) was training under Dr. Alton Ochsner, who was chairman of surgery at Tulane University School of Medicine. In his later years, DeBakey recalled advice given to him by Dr. Ochsner: "Early to bed, early to rise, work hard, and publicize." In 1941, DeBakey volunteered for the army medical services, where he ultimately rose to rank of Colonel and created army auxiliary surgical groups. When he realized the best-trained medical personnel were at base hospitals away 


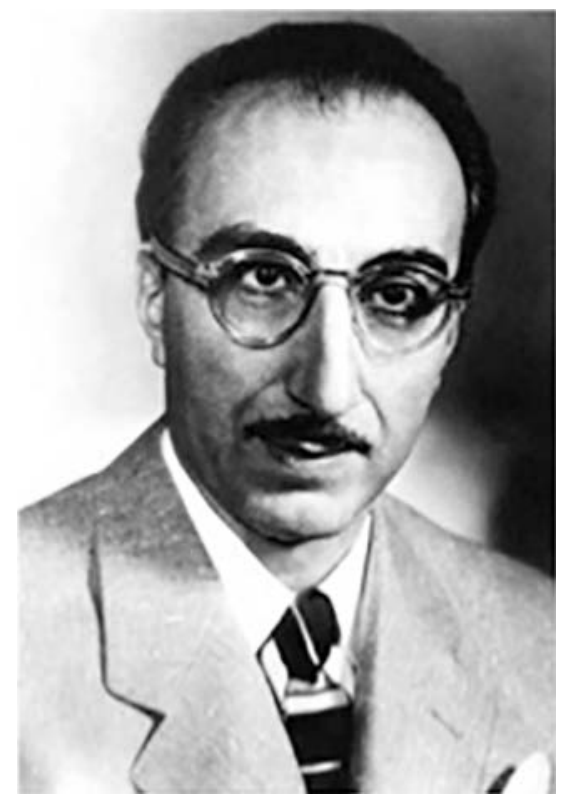

Photo 9. Michael E. DeBakey, M.D., circa late 1940s.

from combat, he moved them to the front lines where they could more promptly treat casualties. Throughout the rest of World War II, casualty deaths plunged from $20 \%$ to $4 \%$, an achievement for which he received the Legion of Merit. The activities of these mobile army surgical hospitals in the Korean War that followed were memorialized in the popular television show, "MASH." After the war, President Truman recruited DeBakey and others to reorganize the Veterans Health Administration (VHA). At DeBakey's suggestion, the VHA education and training programs were to become affiliated with medical schools. While this was going on, DeBakey was gaining national recognition for his efforts to transfer the Army Medical Library to the National Institutes of Health. This led to the establishment of the National Library of Medicine.

In 1947, DeBakey received his first invitation from Dr. Walter $H$. Moursand, dean of Baylor, to become chairman of the college's Department of Surgery. It took three visits over the next year to persuade him to accept. Even after arriving, he found himself unwelcomed by a large segment of the Houston surgical community because of his insistence on board certification and hands-on patient care. What convinced him to stay was his recognition of the vast potential of the Texas Medical Center. At first, DeBakey was to work at the old Jefferson Davis Hospital. That failing to develop, Moursand arranged a 20-bed surgical service for him at Hermann Hospital that also failed to materialize as he was given teaching privileges only. As he was preparing to resign, an unexpected gift arrived: after lobbying by DeBakey, the 1,000-bed naval hospital in Houston was given to the Veteran's Health Administration. It became Baylor's first affiliated hospital.

After taking over the VA Hospital in 1949, DeBakey turned his sights back to Jefferson Davis Hospital. He introduced himself to Mr. Ben Taub, the hospital board chairman. The two bonded immediately, becoming lifelong friends and collaborators (Photo 10). Through their efforts, an agreement was reached with the hospital's medical staff that the Baylor staff would assume responsibility for the care of patients, emergency room services, and outpatient clinics. Now there were two hospitals in which Baylor physicians could make teaching rounds. Baylor's next affiliation was a 30-year agreement made with The

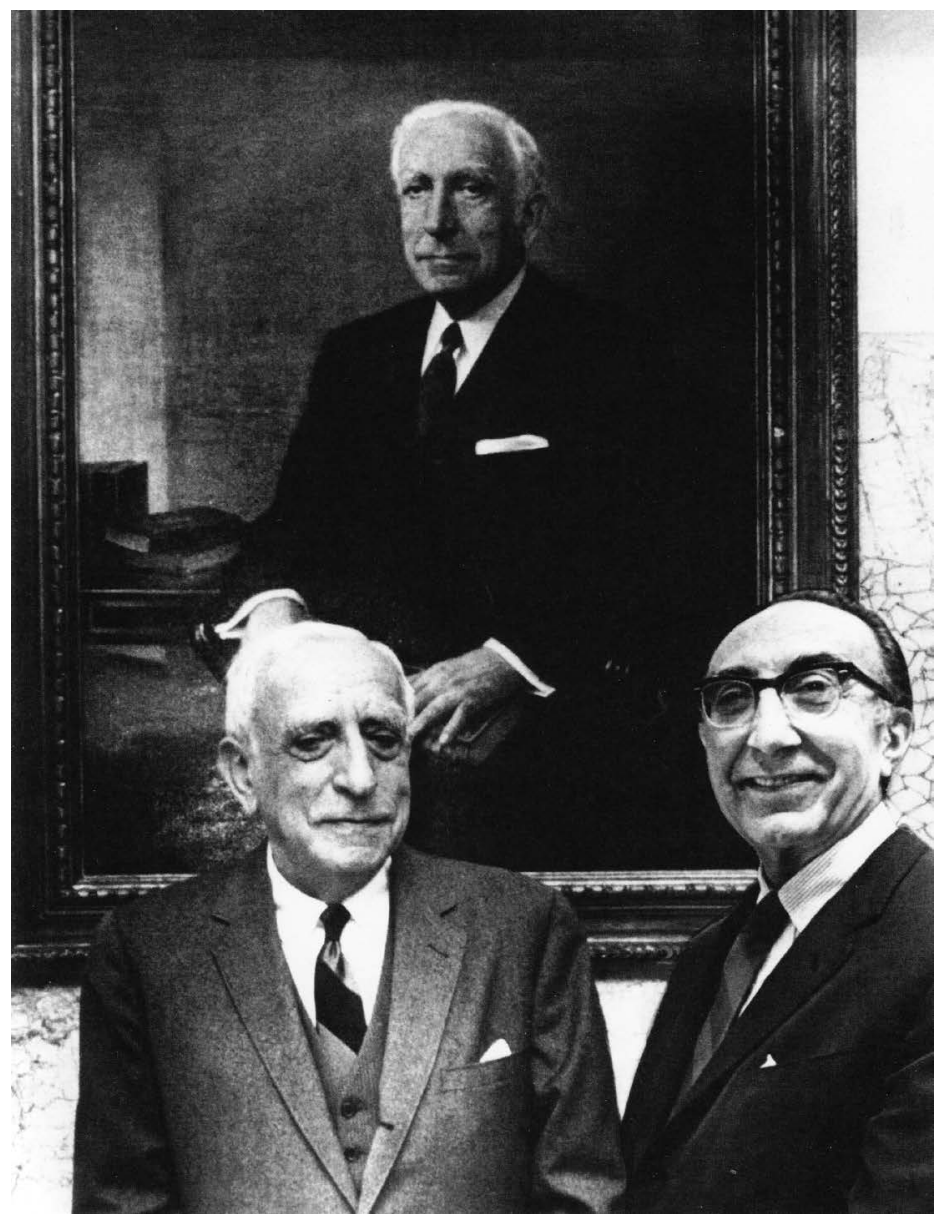

Photo 10. Hospital board chairman Ben Taub with Michael E. DeBakey, M.D., circa 1950s.

Methodist Hospital in 1951, thus creating one of the nation's first multihospital teaching programs.

In 1950, Dr. George C. Morris joined Baylor as the first resident in general thoracic surgery, practicing vascular and cardiac surgery at Methodist for the next 46 years (Photo 11). That same year, Dr. Denton Cooley also joined DeBakey at Baylor after completing his pediatric surgical training at Johns Hopkins University and a year with Dr. Russell Brock in London. Dr. Brock famously remarked, "It stands to reason that the world will not produce a second Denton Cooley, and frankly, I have my doubts if the world could handle another one."

As DeBakey and Cooley worked successfully on aortic aneurysms, DeBakey was determined to "work his way around the aorta" and devise surgical procedures to improve the prognosis for patients with aortic diseases. One of his first ideas was to use a homograph to repair an aneurysm, and his initial thought was to harvest them himself from autopsies at Jefferson Davis Hospital.

On June 29, 1953, Time magazine reported the successful repair by DeBakey and Cooley of a syphylitic thoracic aortic aneurysm with a homograph - the first of its kind. Another first that year was a carotid endarterectomy, also performed by DeBakey. As demand for homografts increased, Dr. DeBakey began looking for a substitute. He thought Vinyon N, a synthetic cloth used to make spinnaker sails, would work. When it was not available, he chose Dacron as a substitute (Photo 12). Having been taught to sew by his mother, he created a Dacron graft, a design that was to be used 


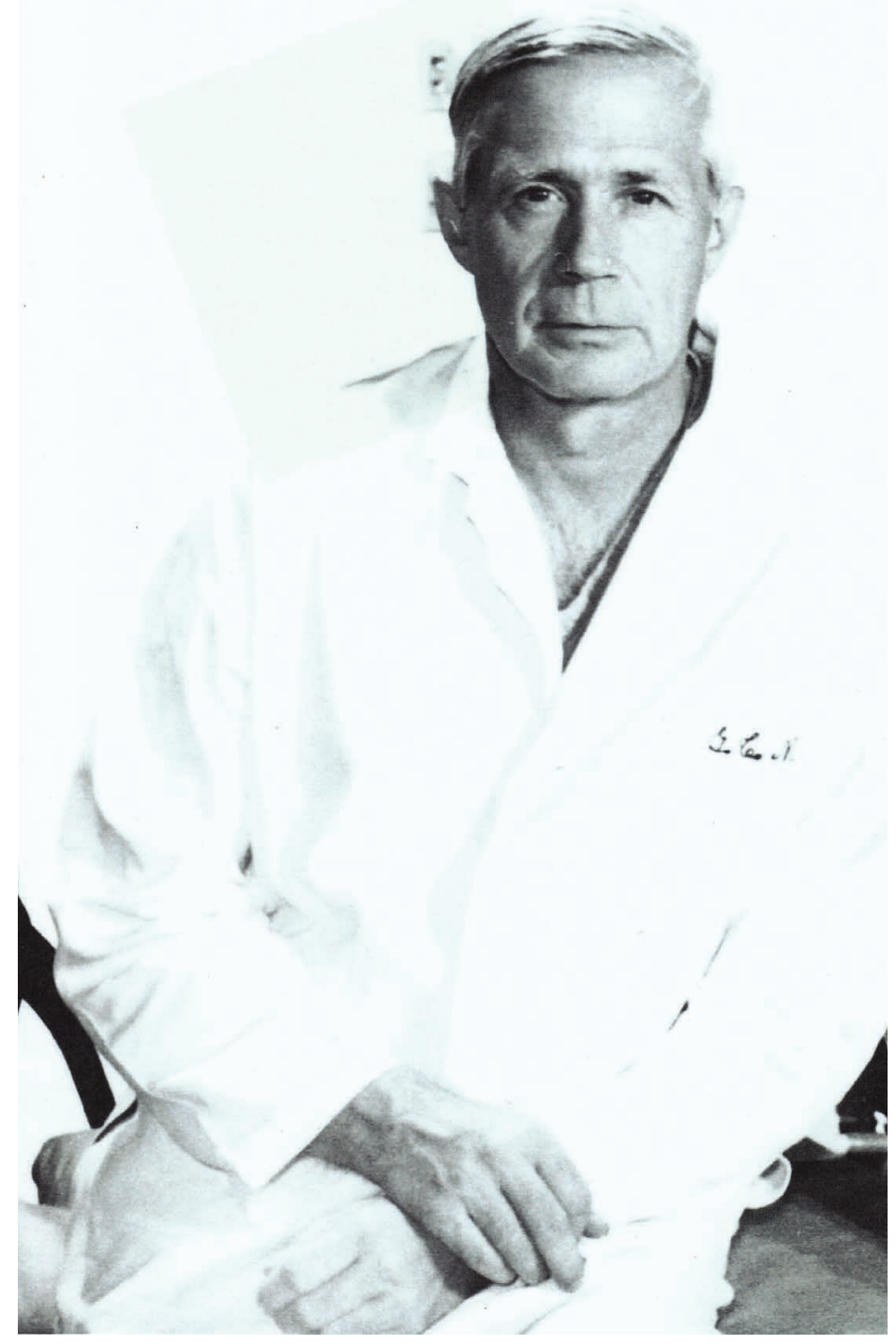

Photo 11. George Morris, M.D., circa 1950s.

many times over the next 4 years by DeBakey, Cooley, Morris, Creech, and a new member of the group, Dr. Stanley E. Crawford, newly arrived from Massachusetts General Hospital. Their work was to serve as a catalyst for the rapid development in the field of reconstructive arterial surgery.

It was during the mid-1950s that DeBakey met another person who would become his collaborator: Mrs. Mary Lasker, director of the Lasker Foundation and widow of Albert Lasker, who died in 1952. She and her husband had been instrumental in lobbying for the establishment of the National Cancer Institute and, based on that model, the subsequent establishment of the National Institutes of Health in 1948. Fifteen years later, she was to bestow upon DeBakey her highest compliment by awarding him The Albert and Mary Lasker Award for Clinical Research.

\section{The Era of Open-Heart Surgery}

In 1953, the Gibbon heart-lung machine was developed at Jefferson Hospital in Philadelphia using the DeBakey pump, a roller pump he devised while a medical student to facilitate blood transfusions (Photo 13). When Texas Children's Hospital opened

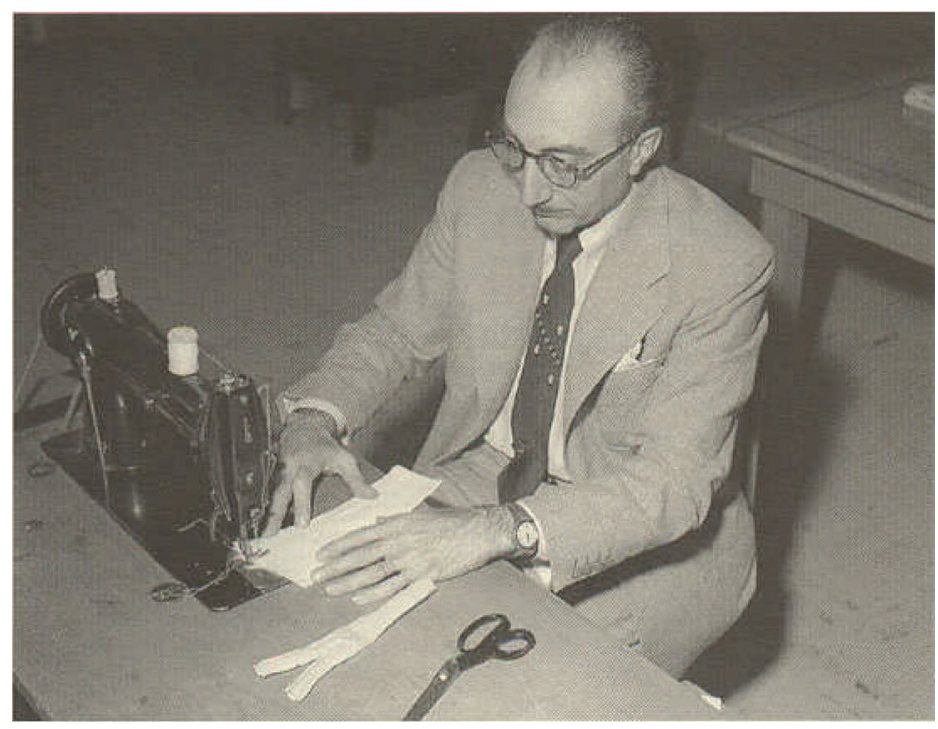

Photo 12. DeBakey sewing a Dacron graft prototype, circa 1950 s.
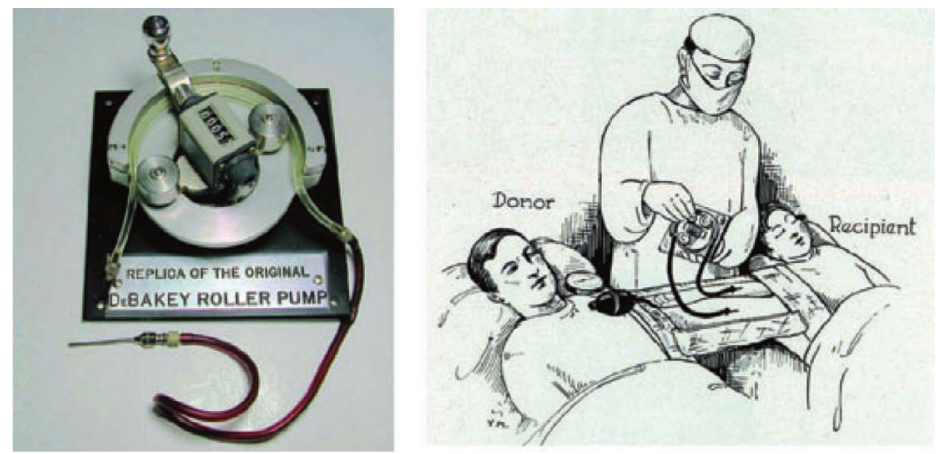

Photo 13. The DeBakey roller pump, circa 1953.

in February of 1954, Cooley began doing palliative closed-heart repairs of certain congenital heart defects.

Then in March, 1955, Dr. John Kirkland began successful openheart surgery at the Mayo Clinic using the Gibbon heart-lung machine modified by Mayo engineers. About the same time, Dr. C. Walton Lillehei and his resident, Dr. Richard DeWall at Minnesota, devised a disposable bubble oxygenator, a model that led Cooley to devise his own bubble oxygenator-affectionately thereafter called the "Cooley Coffee Pot." Using this equipment, Cooley successfully corrected a ventricular septal defect in 1956, marking the beginning of the open-heart era in Houston.

Success of the heart-lung machine prompted DeBakey to think of longer-term support for heart failure patients. This led him to establish a research laboratory at Baylor dedicated to the development of a mechanical heart pump, a version of what was later to become known as a ventricular assist device. His concern for postoperative patients who did have complications led him to conceptualize a surgical cardiovascular intensive care unit at Methodist-another first of its kind. Dr. Edward Dennis, (Photo 14), recruited by Baylor in 1953 as chief of cardiology at Jefferson Davis Hospital, moved to Methodist in 1956 to help train nurses for this unit and to head the new cardiorespiratory laboratory, to be run by Drs. Ray Skaggs and Jim Alexander, on the ninth floor of The Methodist Hospital.

In 1958, DeBakey introduced the patch graft angioplasty procedure, extending treatment to occlusive lesions in smaller arteries. The next year, Dr. Arthur Beall joined DeBakey after 


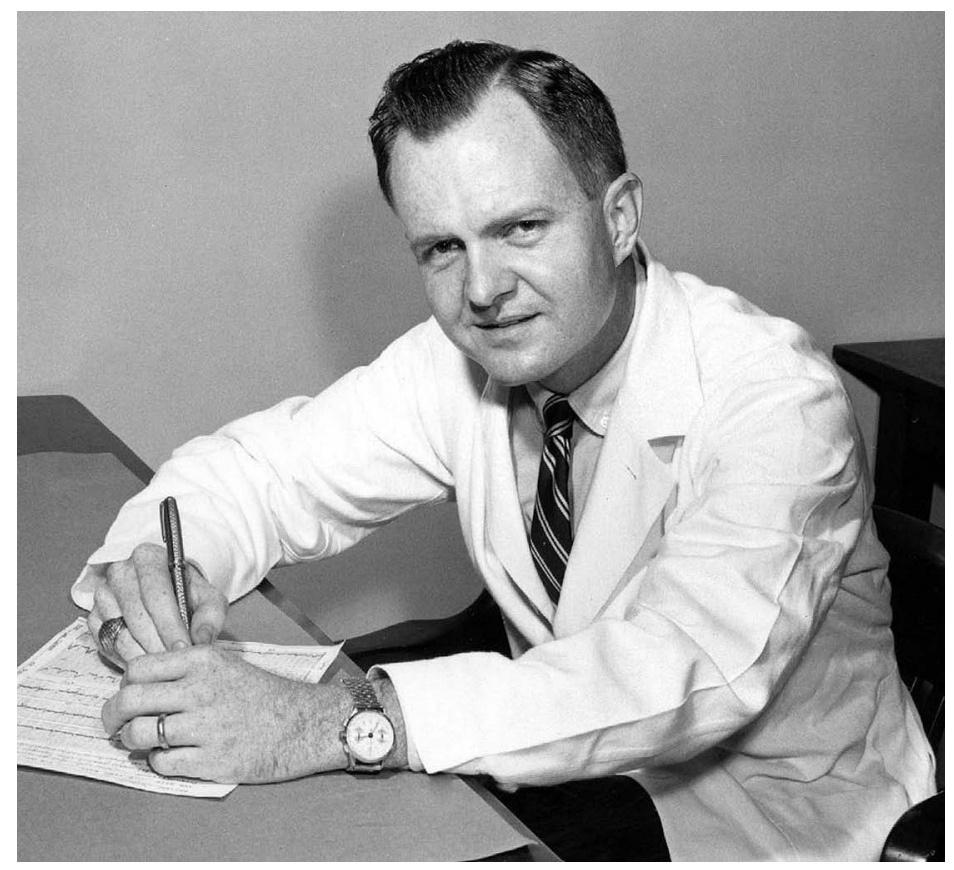

Photo 14. Edward Dennis, M.D., circa 1953.

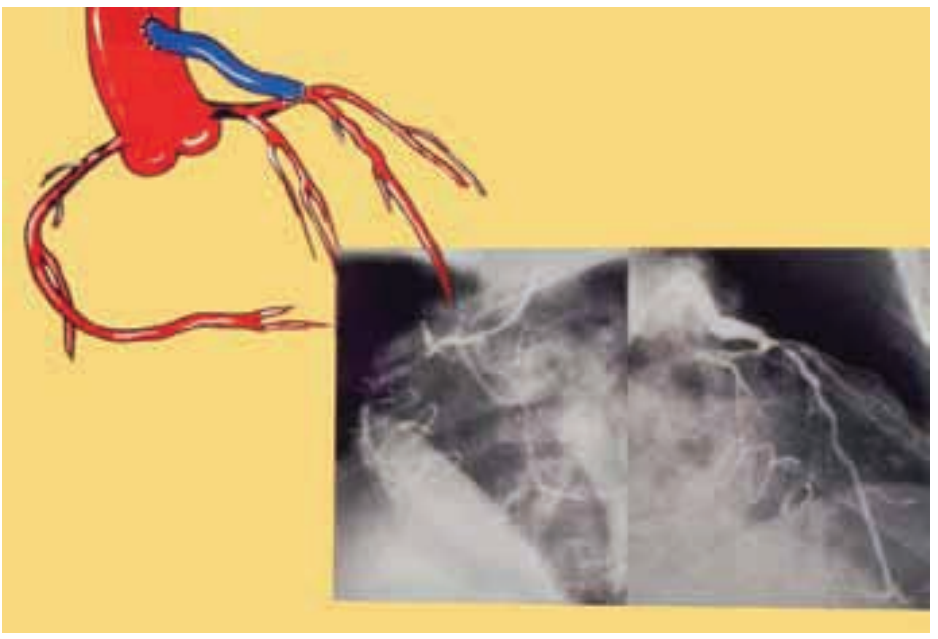

Photo 15. Images of first coronary artery bypass performed by doctors Ed Garrett and Jimmy Howell.

finishing his surgical residency at Baylor. Beall subsequently devised the Beall teflon disc valve that was used for mitral valve replacement for about 10 years.

In 1960, while recovering from a fractured hip at The Methodist Hospital, Mrs. Fondren had a commanding view from her room of a vacant piece of property. "We have to build something on that property," she kept repeating. So marked the conceptual beginning of the Fondren-Brown Cardiovascular and Orthopedic Research Center, which broke ground 4 years later on October 27,1964 . Hearing of these plans, Cooley preferred to have this type of facility closer to Texas Children's and St. Luke's hospitals. For this reason, among others, he decided to create a specialized cardiovascular facility of his own. So was chartered the Texas Heart Institute on August 3, 1962.

Meanwhile, in 1961, Domingo Liotta, formerly with Dr. Willen Kolff and his artificial organ program at the Cleveland Clinic, joined DeBakey's research laboratory in their quest to create an implantable heart pump. Also that year, Dr. Ed Garrett

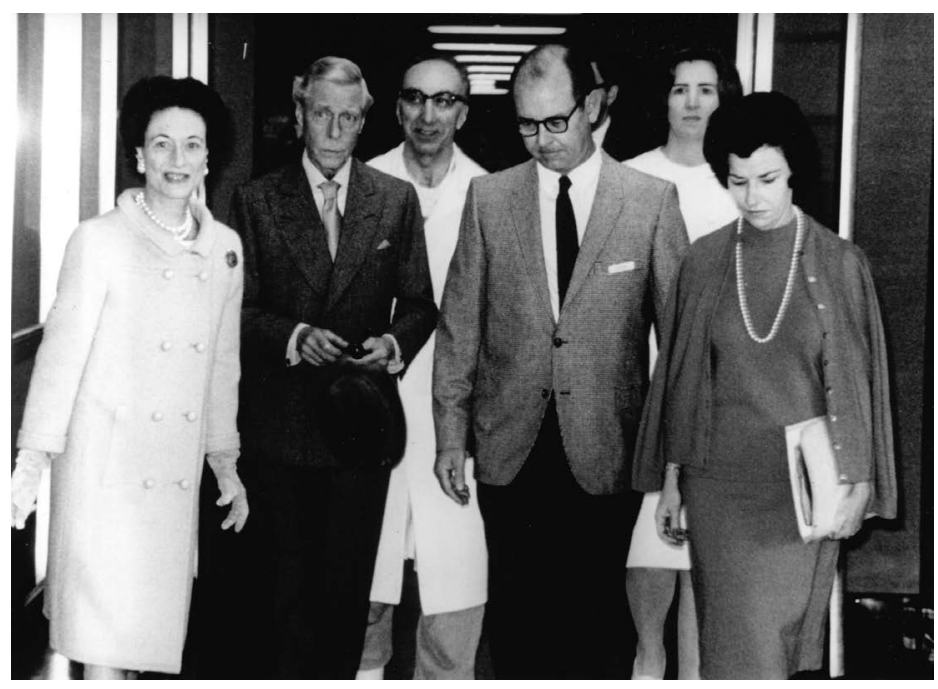

Photo 16. The Duke and Duchess of Windsor with Methodist administrator Ted Bowen, circa 1964

completed his cardiovascular surgical training at Baylor and joined the DeBakey staff. It was he and Jimmy Howell who in 1964 performed the first aorta-to-coronary artery bypass with a vein graft to the left anterior descending artery (Photo 15). While highly successful, it was not reported for 7 years. During that time, Dr. René Favaloro in Cleveland performed an aortocoronary bypass with a vein graft in 1967 and published the results in 1968, thus being generally credited, incorrectly, for the first coronary artery bypass operation.

On December 16, 1964, the Duke of Windsor was referred to DeBakey for repair of an abdominal aortic aneurysm (Photo 16). Asked by the press when he returned for a follow-up visit a year later why he came to Houston to see Dr. DeBakey, the Duke replied, "Because he is the maestro." Shortly thereafter, Dr. DeBakey's picture appeared on the May 28, 1965 cover of Time magazine (Photo 17). The accompanying story identified DeBakey as the "Texas Tornado," describing his 20-hour days and the "incredible drive for perfection, the unending concern for his patients, and the utter domination of his life, by his profession." In the same article, he reasserted his dedication to research for creation of a total artificial heart. That same year, $\$ 40$ million was approved by the National Institutes of Health to start planning for a total artificial heart program. DeBakey's portion of that pie was $\$ 4.5$ million, marking the beginning of the Baylor-Rice University Artificial Heart Program. It was that same year that Drs. Edward B. Dietrich and George P. Noon finished their cardiovascular surgical training and joined DeBakey. While Dietrich chose to leave in 1970 with Dr. Sam Kinard to establish the Arizona Heart Institute in Phoenix, Noon teamed with DeBakey to become known internationally for his pioneering research and clinical expertise in organ transplantation and assist devices (Photo 18).

In the 2 years after Congress mandated federal funding for the artificial heart program, at least three U.S. surgical research laboratories were researching the feasibility of implanting an artificial heart in the humans. In addition to the Baylor-Rice program, Dr. Willem J. Kolff in Cleveland and Dr. Adrian Kantrowitz in Brooklyn also were engaged in similar research, but DeBakey believed the public was entitled to know what was being achieved. He stated publicly in January, 1966, that "an artificial heart should be placed in the human within a year". On April 21st of that year, a patient was scheduled for a mitral valve replacement 


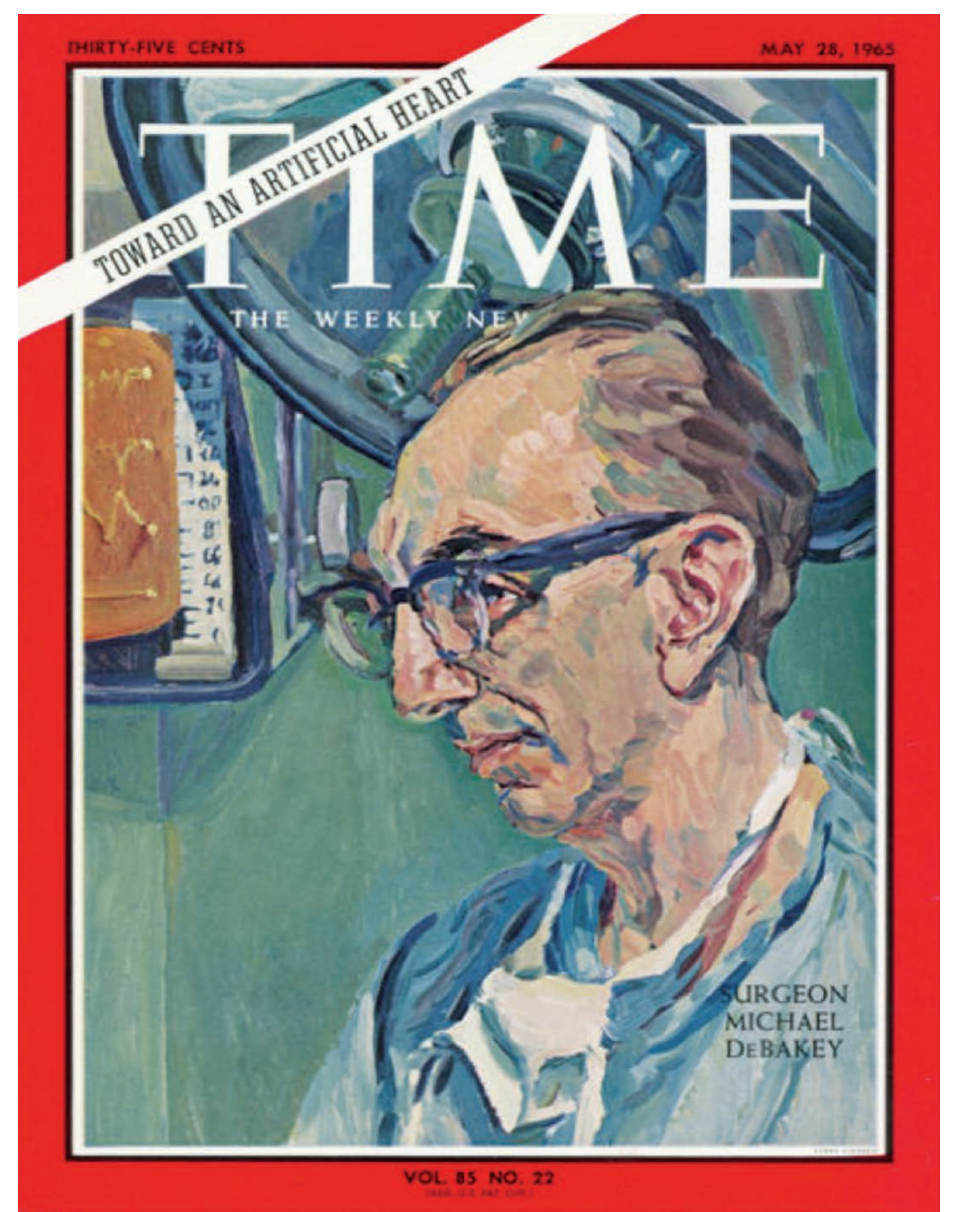

Photo 17. DeBakey on the May 28, 1965, cover of Time magazine.

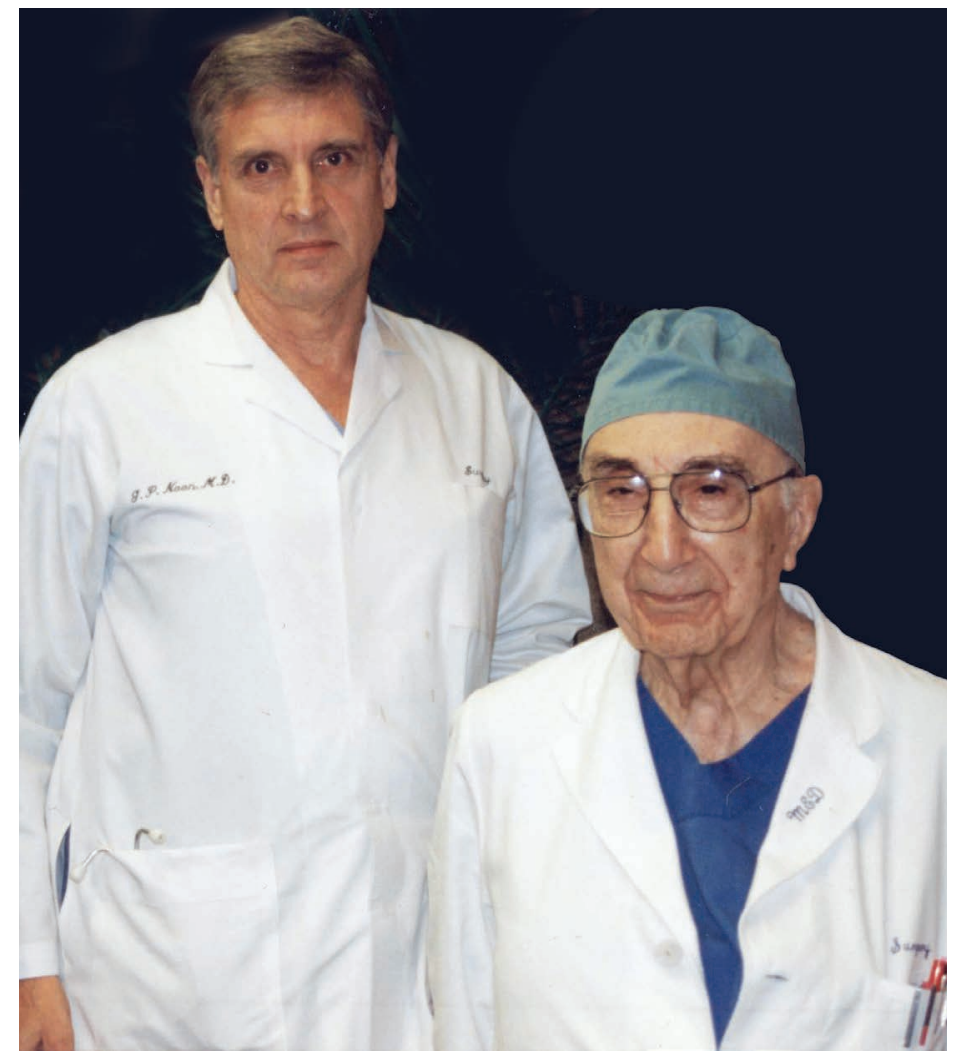

Photo 18. Doctors George Noon and Michael DeBakey, circa 1980s.

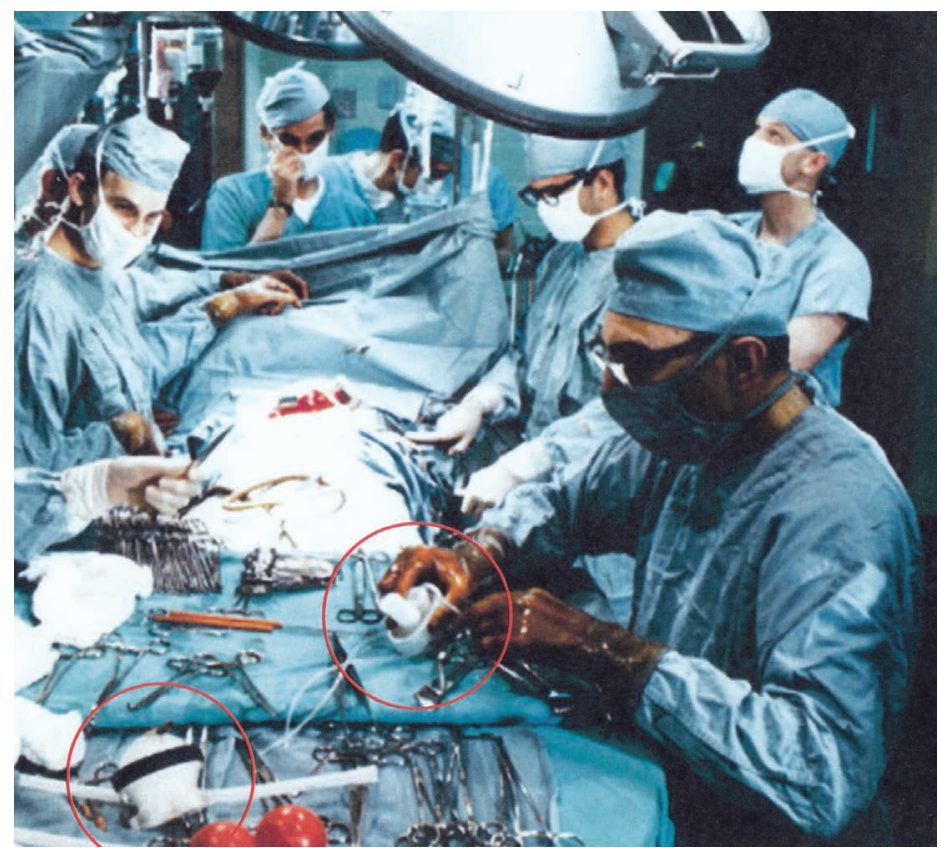

Photo 19. DeBakey performing surgery using early ventricular assist device, circa 1966.

at Methodist. When, after valve implantation, his heart failed to recover, he became the first recipient of a mechanical heart pump we now know as a ventricular assist device (Photo 19).

The world awakened in December, 1967, to the first heart transplant by South African doctor Christian M. Bernard. This was soon followed by the ninth heart transplant worldwide and the first successful one in the United States by Cooley at the Texas Heart Institute. By the end of 1968, Cooley had performed 17 heart transplants. Nationwide news coverage then began to identify him as the "heart transplant man" and DeBakey as the "artificial heart man." This characterization disappeared on August 31, 1968, when DeBakey and his five-member surgical team at Methodist performed the world's first multiorgan transplant: two kidneys, a lung, and a heart from the same donor to four different patients. By December, 1968, only three of Cooley's 17 patients were living and four of DeBakey's ten, the result of ineffective immunosuppressant drugs. In 1969, President Johnson awarded DeBakey the Presidential Medal of Freedom.

Then a bombshell. On April 4th, 1969, at the Texas Heart Institute, Cooley, with the help of Liotta, implanted a total artificial heart into Haskell Karp—an artificial heart eerily similar to the DeBakey design. DeBakey read about it the following morning while away in Washington, DC. Karp did receive a human heart 65 hours later but died 30 hours after that. This event led to legal, ethical, and personal conundrums for all involved including the National Heart Institute, The American College of Surgeons, and Baylor College of Medicine. Dr. DeBakey throughout it all and forever after never made a public statement. Cooley subsequently resigned from the Baylor academic faculty. From that point on, the two surgeons each went separate ways (Photo 20). Two imminent bioethicists, Renee C. Fox and Judith P. Swazey, subsequently published an objective, in-depth review of the event in The Courage to Fail and concluded, "In our view, this case and its outcome shows the medical and law professions, and the societies to which they belong, have not satisfactorily dealt with the social, moral, and legal issues involved in therapeutic innovation with human subjects." 


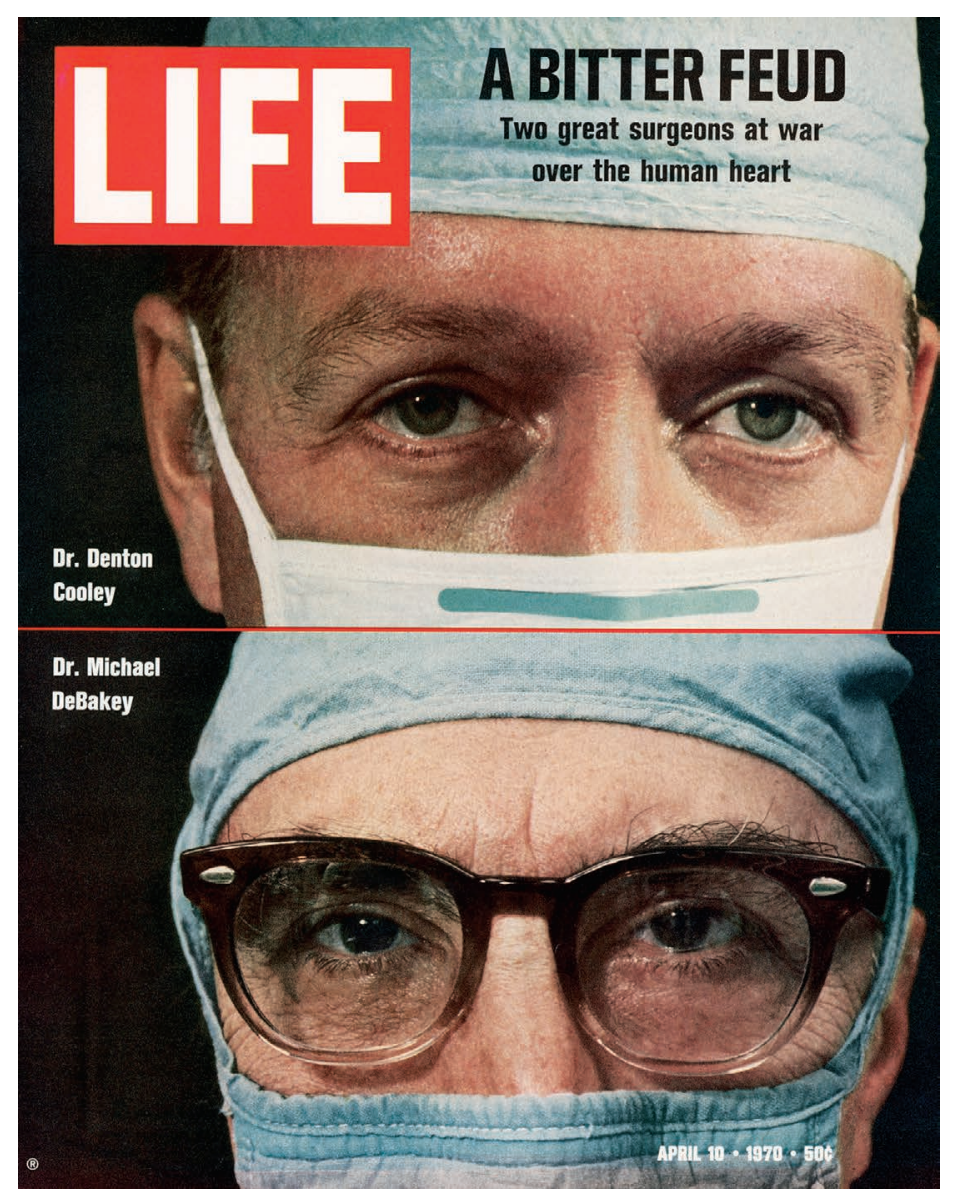

Photo 20. Time magazine cover on April 10, 1970, depicting the DeBakeyCooley split over the first artificial heart surgery.

In other areas of cardiovascular surgery, Dr. Stanley Crawford became known as "Mr. Aorta" because he operated on the whole aorta from top to bottom (Photo 21). In 1985, Diseases of the Aorta was published with his son, Dr. John L. Crawford, II. Another of his legacies was the early Wednesday morning Vascular Case Conferences he chaired whereby he engaged everyone in case discussions. No one escaped, especially cardiologists. The learning curve was high.

The late 1960s and 1970s were marked by an avalanche of patients coming to physicians at Methodist, including celebrities such as Jerry Lewis and Marlene Dietrich. At one time, the Chapman Group was rounding on 120 patients daily, with a similar number seen by DeBakey. But it was not all work. Cooley and Chapman, for example, enjoyed playing for "The Heartbeats" - an all-physician band originally formed for their own enjoyment but often found performing for fundraisers and medical events both in Houston and nationally. And the Russians discovered that DeBakey was also an expert pool player.

\section{The Advent of Interventional Cardiology}

By this time, you may be wondering how surgeons identified the vascular lesions upon which they were operating. Before catheter techniques for angiography became popular, DeBakey and his colleagues preferred to perform direct needle arterial puncture under general anesthesia. In the X-ray department, a special "bucky table" was designed with a movable steel plate that covered one-half of the underlying X-ray cassette. As the injected contrast traveled distally in the vascular tree, the surgeon moved

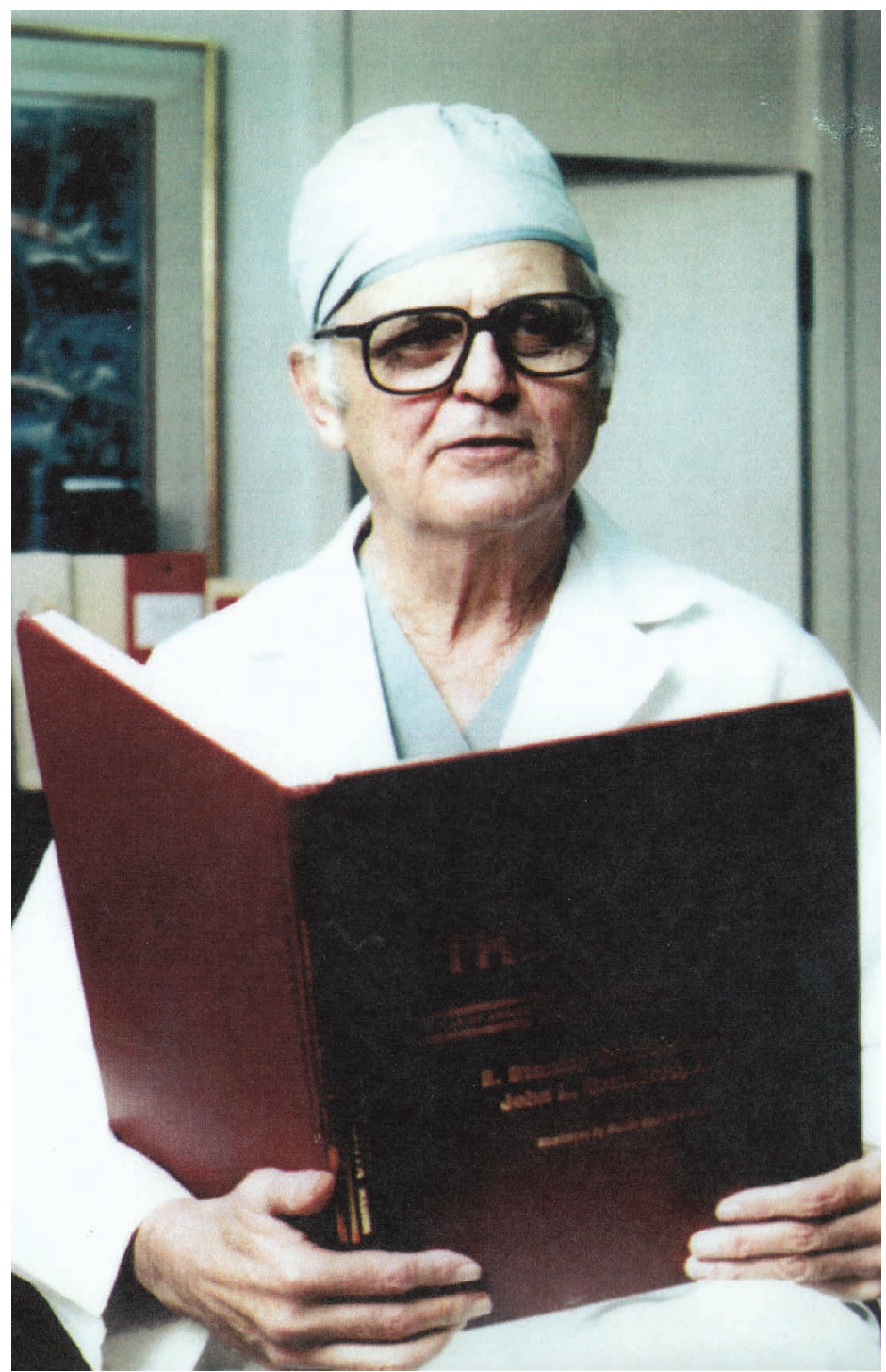

Photo 21. Surgeon Stanley Crawford, otherwise known as "Mr. Aorta," circa 1980 s.

the plate to expose the distal portion of the cassette. In this manner, pictures were obtained for the carotid and peripheral vessels and abdominal aorta. It was referred to as the "voodoo doll technique" because the patient could end up with multiple needle sticks in as many as seven different arteries. Then, in 1965, Dr. Jack Roehm, a radiologist trained in interventional radiology at the University of Minnesota, came to Methodist. The surgeons gradually turned over the diagnostic angiographic procedures to him, and thus was born the interventional radiology department at The Methodist Hospital.

In March of 1968, I accepted an invitation from Don Chapman to move to Houston with the proviso that I obtain a clinical appointment at Baylor College of Medicine as well as an echocardiographic machine to continue the work I had started in Philadelphia in cardiac ultrasound. This led to the establishment the following year of the first echo laboratory in the Southwest at Methodist. Also in 1968, a search for a new chairman for the Department of Medicine was undertaken. That person became Dr. Henry Dean McIntosh, formerly chief of the cardiovascular division at Duke University School of Medicine. He immediately established a section of cardiology at Methodist, bringing with 

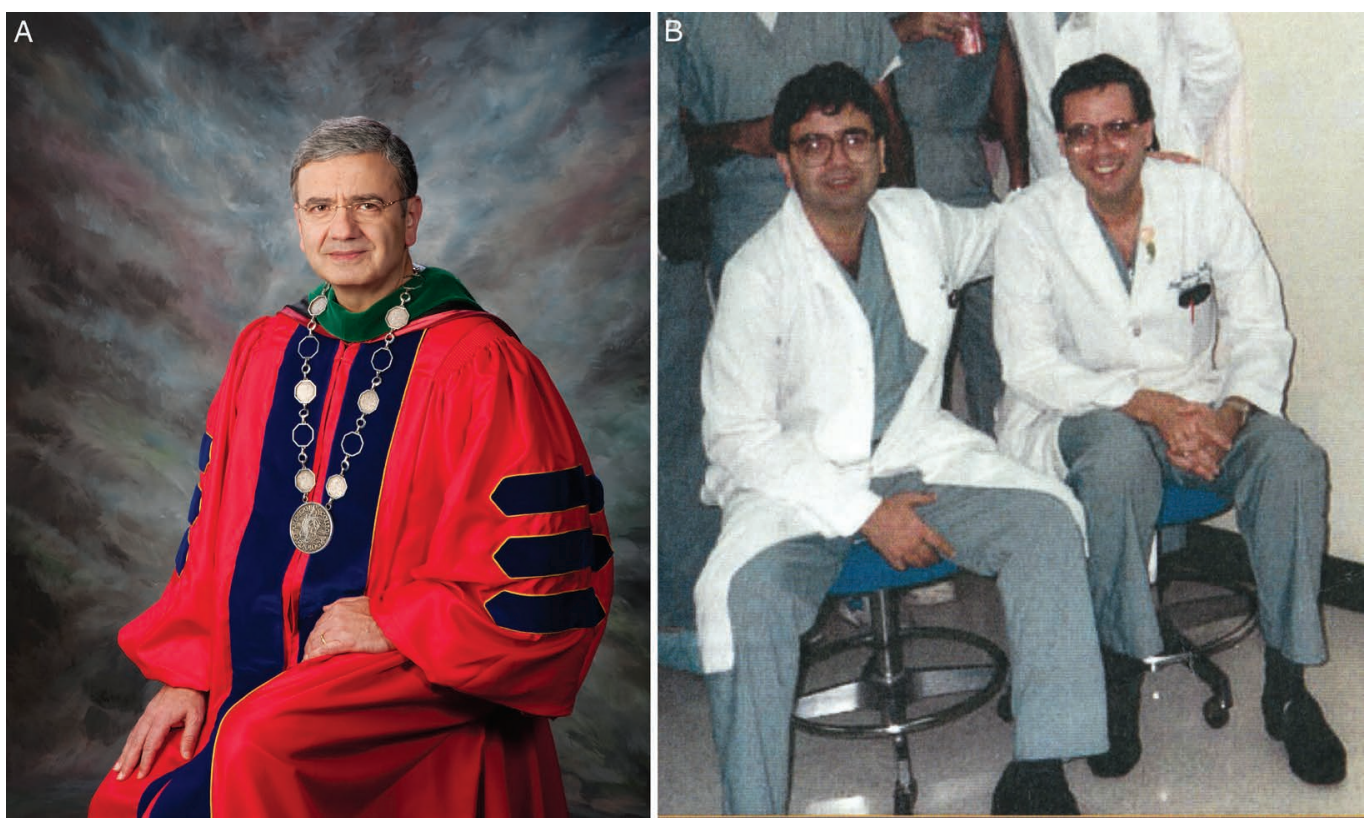

Photo 22. (A) William Zoghbi, M.D.; (B)

Zoghbi (left) with Miguel Quinones, M.D.

him Dr. Kinsman "Ted" Wright to oversee a new noninvasive diagnostic cardiology laboratory. Both the Wright and Winters' echo labs operated independently until 1978, when Dr. Miguel Quiñones joined Methodist and the echo labs were merged. Dr. Mark Entman then joined the cardiovascular research center as chief of cardiovascular sciences.

In his 7 years as chairman of the Department of Medicine, McIntosh left many strong legacies. He elevated the medical resident training programs to national ranking. He confronted problems head on and worked hard to keep a good working relationship with his faculty. He served in 1974 as president of the American College of Cardiology, the first of three from this institution. In October, 1976, he resigned as chairman and left the next year to move back to his home state of Florida. His chief residents established the Henry D. McIntosh Award to be given annually to the outstanding medical resident in internal medicine.

Well before his departure, McIntosh and Dr. Joe Merrill were successful in recruiting Dr. Antonio Gotto to join the medical department. Gotto became chief of the new section of arteriosclerosis and lipid protein research at Baylor and Methodist. In his 6 years at Methodist, he had become recognized worldwide. So it was no surprise to anyone that in February of 1977, he was appointed chairman of the Department of Medicine at Baylor and Methodist. One of his first recruits in the building of an academic cardiology faculty was Dr. Richard Miller as chief of cardiology from the University of California at Davis. His second was a reconfirmation letter to Dr. Miguel Quiñones, who was returning from military service and had been recruited by McIntosh to join the faculty in 1977.

\section{Perspectives: Sentinel Events in Cardiovascular Medicine}

Time does not permit me to review for you in any detail the many exciting events over the next 35 years that lead to the present-day Houston Methodist DeBakey Heart \& Vascular Center. You will have to read the book for the details, but I will highlight some sentinel events through the careers of five individuals.

\section{Jean Nelson}

When I came to Houston in 1968, Chapman came through with his promise to provide me with an ultrasound machine. I had learned about cardiac ultrasound in 1962 from a friend, Dr. Claude Joyner at the University of Pennsylvania, who had introduced the technique to the United States. Through him I came to know Dr. Inge Edler, the Swedish cardiologist who provided the first cardiac ultrasound recordings in 1953 and who received both the Lasker Award in 1977 and a Presidential citation in 1991 from the American College of Cardiology (ACC). Last year, I was privileged to be invited by the Edler family to attend the 60th anniversary of that publication.

When the new echo machine arrived, I needed a technician. Jean Nelson, a young medical technician working for Chapman, agreed to work with me. She became expert at obtaining the echo records and interpreting the studies (refer to Online Video 1). She also gave names to some of the abnormalities we discovered-the most memorable being the "snake tongue sign" for a prolapsed mitral valve resulting from a ruptured chord. It was never published, nor was our very early recognition of aortic valve insufficiency from the fluttering of the aortic valve seen on the M-mode echo. Jean was extraordinarily talented, and over the 40 years that she worked at The Methodist Hospital, she became director of all the cardiac diagnostic laboratories, including the cath lab, before she retired. Jean is truly one of the legends of this institution. Today, the echo lab is world renowned for its contributions to the clinical world of echocardiography by Drs. Quiñones, Zoghbi, Nagueh, and their colleagues (Photo 22).

\section{Jimmy Frank Howell, M.D.}

Then there is Jimmy Frank Howell, who graduated number one in his Baylor medical school class and practiced cardiovascular surgery here for nearly 50 years. He might still be operating were it not for an unfortunate accident a year or more ago that robbed him of vision in one eye. He is not known as a worldwide lecturer; instead, he preferred to let others do that while he perfected his skills in the operating room (refer to Online Video 2). He has his mark on nearly 30,000 patients, including 


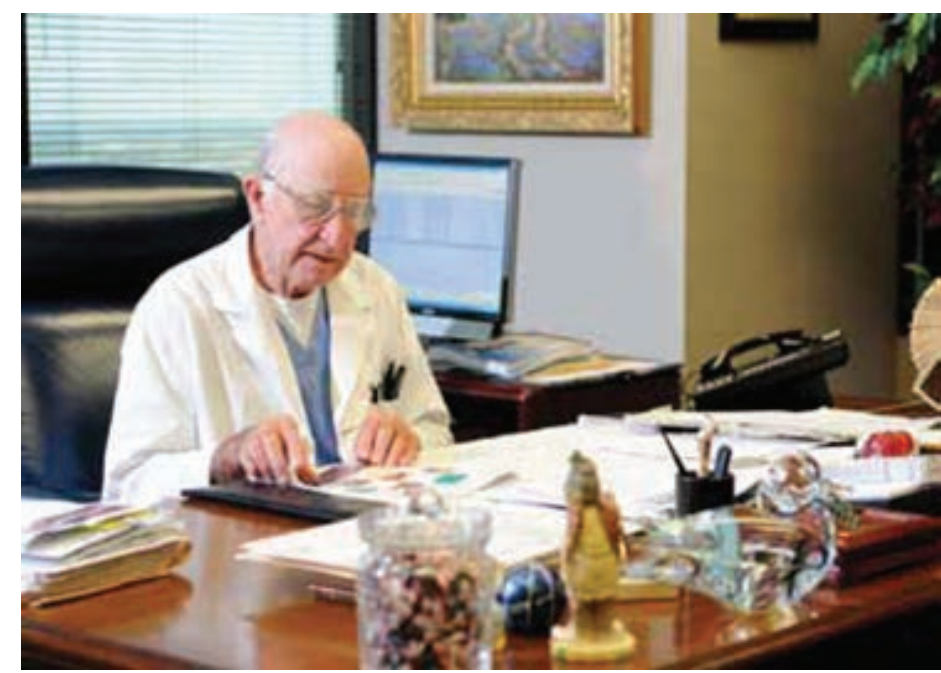

Photo 23. Jimmy Frank Howell, circa 1980s.

me and my wife. There is a very large rolodex on his desk with the names of every patient he treated (Photo 23). His records are so complete we were able to publish a record of some 28,000 patients and procedures done over a 40 -year period. From day one, his statistics for mortality and morbidity were better than any benchmark ever published. As recently as 2 to 3 years ago, the veteran nurses in the Fondren ICU told me, "He still has the best hands and best judgment." This year, a chair was established here in his name in the Department of Cardiovascular Surgery. Two years ago, a celebration was held to commemorate his 80 years of age and 50 years at Baylor. I wrote the following limerick in celebration of that occasion:

\section{Ode to Howell}

Howdy Pardner, my name is Howell

And not yet ready to throw in the towel

Eighty is the age

Still turning the page

While walking the halls on the prowl.

At Baylor, fifty years have passed

In a flash, hard to believe so fast

I paid them my dues

For them all good news

Like money in the bank while I last.

Many patients have become good friends

So they and I hope it never ends

But the truth of the matter

Says the mad Hatter

Really depends on how well one mends.

Mending after one of Howell's jobs

Is as sure as eating corn on the cob

When ripe in the summer

It's never a bummer

And enjoyed by oodles of mobs.

He has been the surgeon's steady Eddie

Always on call and at the ready

For come what may

To this very day

Scalpel in his grip and hand really steady.
He's been known to have a sharp tongue

And more than one resident's been stung

But it's all for the best

As they learn not to jest

With the master at the top of the rung.

So somewhere around now, we can say

This is Dr. Jimmy Frank Howell's Day

Whether eighty or fifty

He's still pretty nifty

So to him we say, "Hip Hip Hooray."

\section{Craig Pratt, M.D.}

Craig Pratt arrived at The Methodist Hospital in 1978, persuaded by Dr. Richard Miller, the chief of cardiology and his colleague at the University of California at Davis, to direct the hospital's coronary care unit, which he has done admirably now for 36 years (Photo 24). His efforts are rewarded annually with a teaching award bestowed on him from his students and residents, who he teaches how to read and interpret medical publications. His research interests have centered around pharmaceutical trials and arrhythmias, particularly atrial fibrillation. He was instrumental in placing The Methodist Hospital in its first clinical trial — the Beta Blockade Heart Attack Trial -and in establishing the hospital's helicopter service to distribute tissue plasminogen activator to outlying hospitals within a 200-mile range (refer to Online Video 3). Pratt served as chair of the Food and Drug Administration's Cardiovascular and Renal Drug Advisory Committee from 1987 to 1993, and he and Robert Roberts co-chaired the ACC Scientific Session in 1991. But what he really is known for is his stewardship of the cardiology fellow training program that has seen his steady hand since 1978. This training program was rated among the half-dozen best programs in the country by the NIH prior to the BaylorMethodist divorce in 2004. Since 2004, Pratt and Judy Paukert, director of the Methodist Graduate Medical Education program, have returned the program to its former esteemed level. In his own inimitable quiet style, he has been the rock upon which this training program has rested for these 36 years, making him another hospital legend.

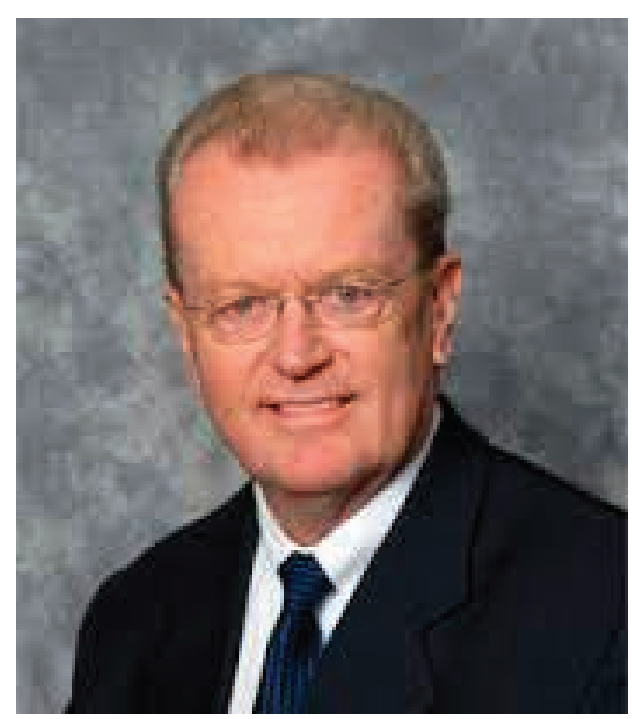

Photo 24. Craig Pratt, M.D., who oversees the Houston Methodist Graduate Medical Education Program, circa 2000s. 


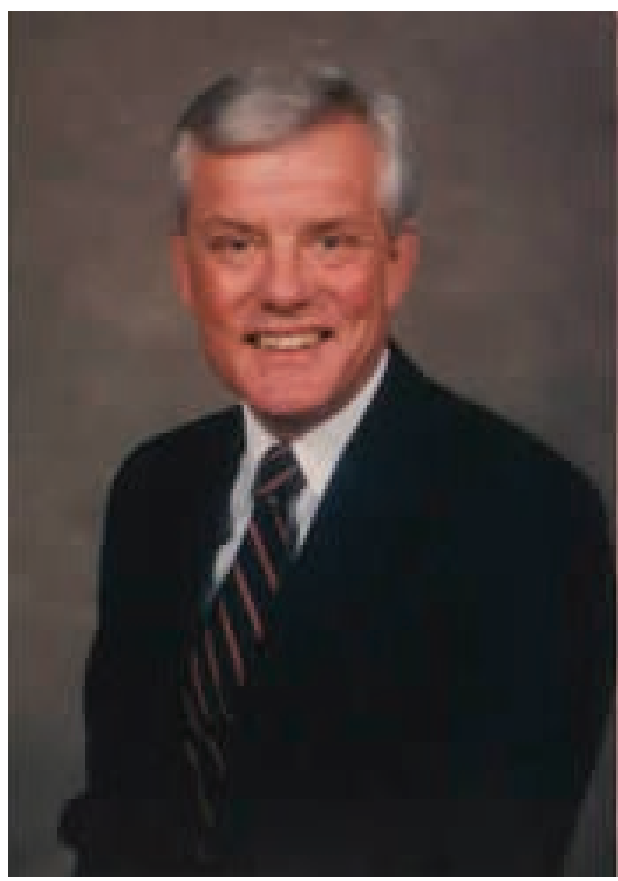

Photo 25. William H. Spencer, M.D., circa 2000s.

\section{William H. Spencer, III, M.D.}

Dr. William H. Spencer, III, valedictorian of his Duke Medical School class and a graduate of their cardiology training program, joined the Chapman Group in 1972 (Photo 25). He led the transfer of pacemaker implantations from the surgeon's realm to cardiology. Working with Medtronic, he was in the forefront of many pacemaker innovations over the years, including devising the subclavian vein angiogram to enable safer means for implanting a pacemaker catheter (refer to Online Video 4). He became director of the Methodist Pacemaker Evaluation Clinic established by Dr. Ted Wright after Wright departed for Chattanooga in 1974. But his real claim to fame came in 1996 when he came upon and popularized a novel treatment for hypertrophic cardiomyopathy while attending a cardiology meeting in Amsterdam. His friend Dr. Ulrich Sigwart, a former Baylor College of Medicine trainee, had just reported treating three patients with hypertrophic cardiomyopathy by injecting alcohol into the first septal perforator, producing a "controlled myocardial infarction," thereby shrinking the hypertrophied septum and removing the left-ventricular outflow tract obstruction. The technique has become known as "alcohol septal ablation" and has served as an alternative to medication or open-heart surgery. Doctors Sherif Nagueh and John Buergler have continued the treatment here since Spencer left for South Carolina in 2000.

\section{Albert Raizner, M.D.}

In 1979, Emory trained cardiologist Albert Raizner moved from the VA Hospital here in Houston to become director of the hospital's hemodynamic laboratory. By this time, Andreas Gruentzig had introduced the concept of balloon angioplasty and was conducting training courses in Zurich, Switzerland. When I heard his original report at the American Heart Association meeting in the fall of 1978, I thought he was out of his mind, but Tony Gotto thought differently. After talking to Dr. Walter Siegenthaler, his friend and chief of medicine at the University of Zurich where Gruentzig was working, Gotto decided to send

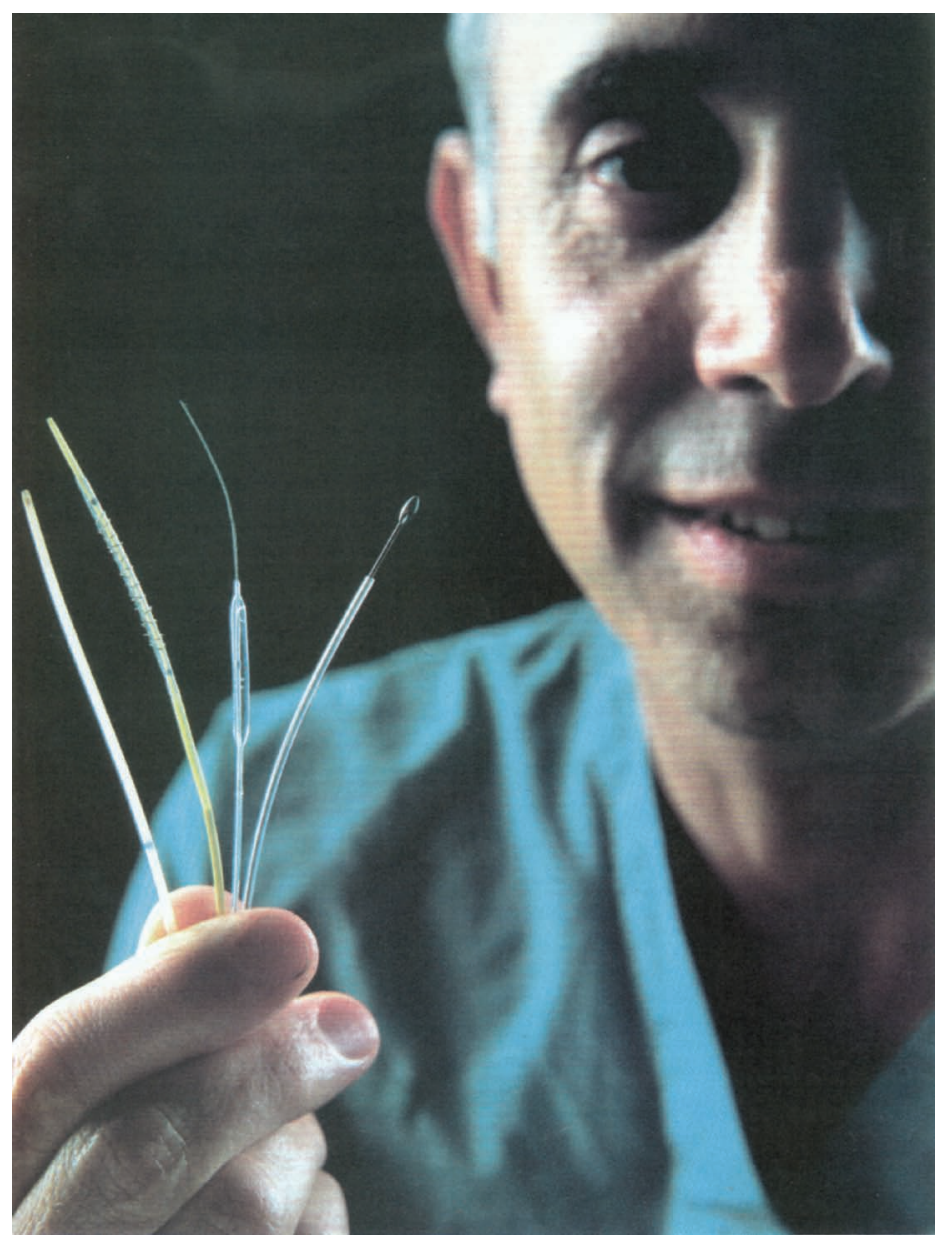

Photo 26. Cardiologist Albert Raizner holding catheter options, circa mid1990s.

a contingent to learn more. So Al Raizner and I were sent in January, 1980, by Ted Bowen while Dr. John Lewis went on his own. We three started doing the procedures at Methodist in March of 1980. It was at that time that cardiologists became doers and the specialty of interventional cardiology was born.

As the angioplasty program grew, it became apparent that up to $50 \%$ of patients developed restenosis within 6 months. Enter the stent age. Raizner and Cesare Gianturco-an interventional radiologist at MD Anderson Cancer Center who had developed a stent for the biliary tree-began working together on stenting a pig model with coronary disease (refer to Online Video 5). Encouraged with the results, Gianturco approached Gruentzig, who had moved from Zurich to Emory. Unfortunately, Gruentzig died in an airplane accident in 1985, but Gary Roubin, his research fellow, subsequently became the first to put a stent in a human coronary artery at Emory. The second one was done at The Methodist Hospital by Raizner in 1988. The Gianturco-Roubin stent underwent a multicenter trial that included Methodist from September of 1988 to June of 1991. This technique also proved problematic with restenosis developing within the stent. Again, Raizner came to the rescue with technology called "vascular brachytherapy" —radiation delivered to the in-stent stenosis by a catheter emitting either beta or gamma radiation from its tip (Photo 26). It worked well but has been rarely used since drug-eluding stents appeared on the scene several years ago, significantly reducing the problem of in-stent stenosis. 


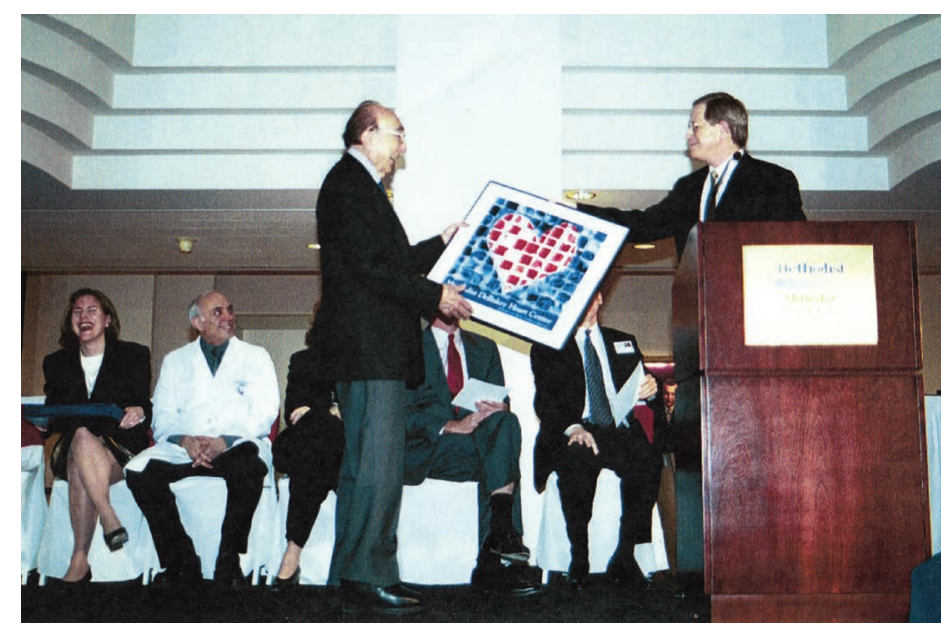

Photo 27. DeBakey with cardiovascular surgeon Joseph Coselli, M.D. at dedication of the Houston Methodist DeBakey Heart \& Vascular Center, 2001.

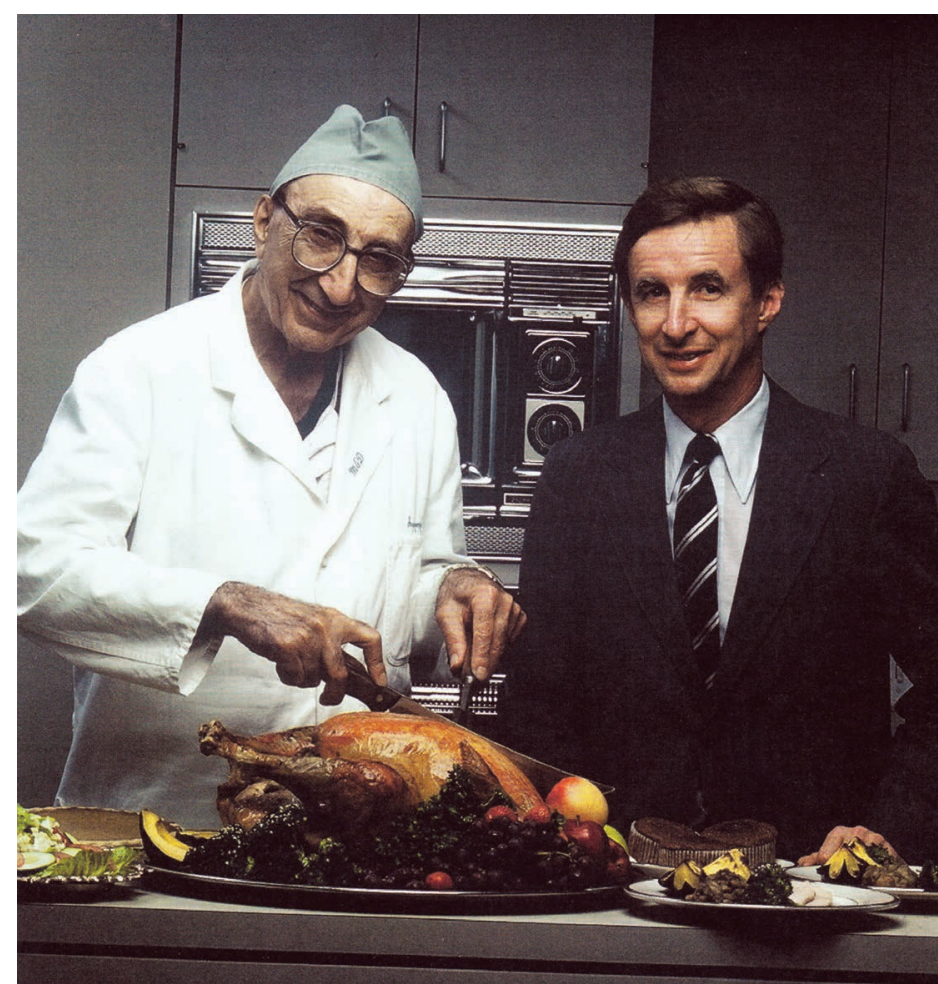

Photo 28. Doctors Tony Gotto and DeBakey promoting the restaurant Chez Eddy, 1981.

But Raizner's signature contribution to The Methodist Hospital came from his incessant pursuit of his dream of a Methodist hospital-based heart center to rival the Texas Heart Institute. With the help of Ron Girotto, Lynn Schroth, and Debra Feigin Sukin, he was instrumental in helping transform the delivery of healthcare at Methodist from one centered on specialties and procedures to one of clinical service lines that enabled the integrated delivery of care and documentation of outcomes. The cardiovascular service line was established at Methodist in 1998. In that year, after the cardiovascular surgery and cardiology program metrics were combined for the first time for the U.S. News $\mathcal{E}$ World Report listing of America's best hospitals, the Texas Heart Institute was named as one of the top 10. But The Methodist Hospital was nowhere to be found.

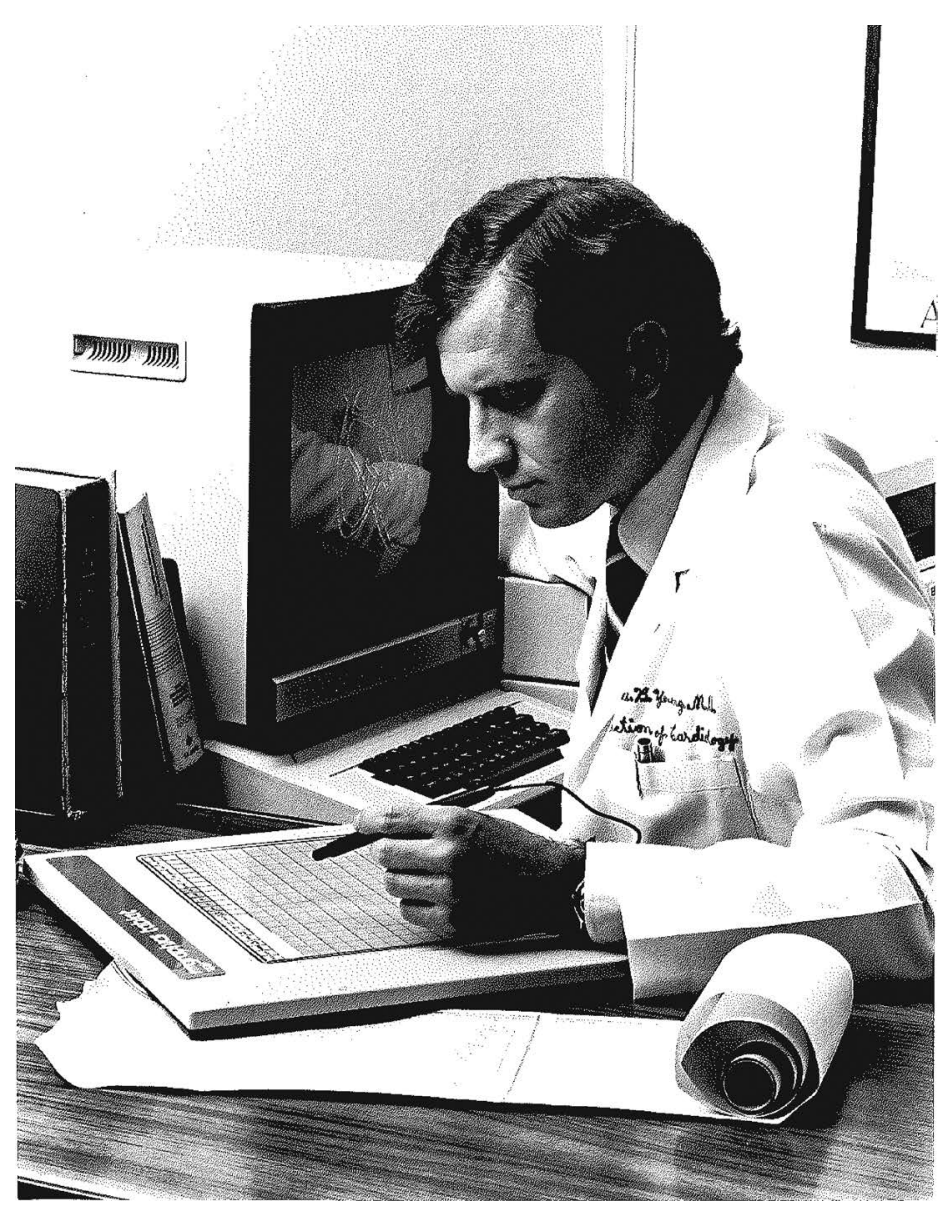

Photo 29. James Young, M.D., first medical director of the Methodist Heart Transplant Program, circa 1980s.

Help then appeared in the person of Dr. Joe Coselli, chief of cardiothoracic surgery at Methodist, who took it upon himself to make the heart surgeons and cardiologists aware of their individual data (Photo 27). Together, Sukin and Raizner formed a steering committee that met monthly over the next year to formalize the concept of a heart center and develop a marketing plan, which they presented to The Methodist Hospital Board of Directors in 2000. It was an easy sell that year, because the U.S. News $\mathcal{E}$ World Report again failed to list Methodist's name among the top 50 heart centers. The Methodist DeBakey Heart Center was subsequently officially dedicated in February of 2001, and Raizner was named its first medical director. It was renamed the Methodist DeBakey Heart \& Vascular Center in 2008.

\section{Conclusions}

There is so much more to be told: Chez Eddy, the heart healthy restaurant in Scurlock Tower that succumbed to the economics of the 1990s, as well as the Chez Eddy Living Heart Cookbook penned by Gotto and DeBakey (Photo 28); the heart transplant performed by Noon and DeBakey on David Saucier, the NASA engineer, that led to the miniaturized continuous-flow pump now under clinical trial; the contributions of George Noon over the years to the transplant program and the establishment of the Noon Award, the design of which appears as the cover of our book the maturation of nuclear cardiology led by Dr. Mario Verani, who died much too young in 2001; the American Correction for mitral valve repair developed by Dr. Gerald Lawrie; the many contributions to the lipid world by Gotto, as well as those of 


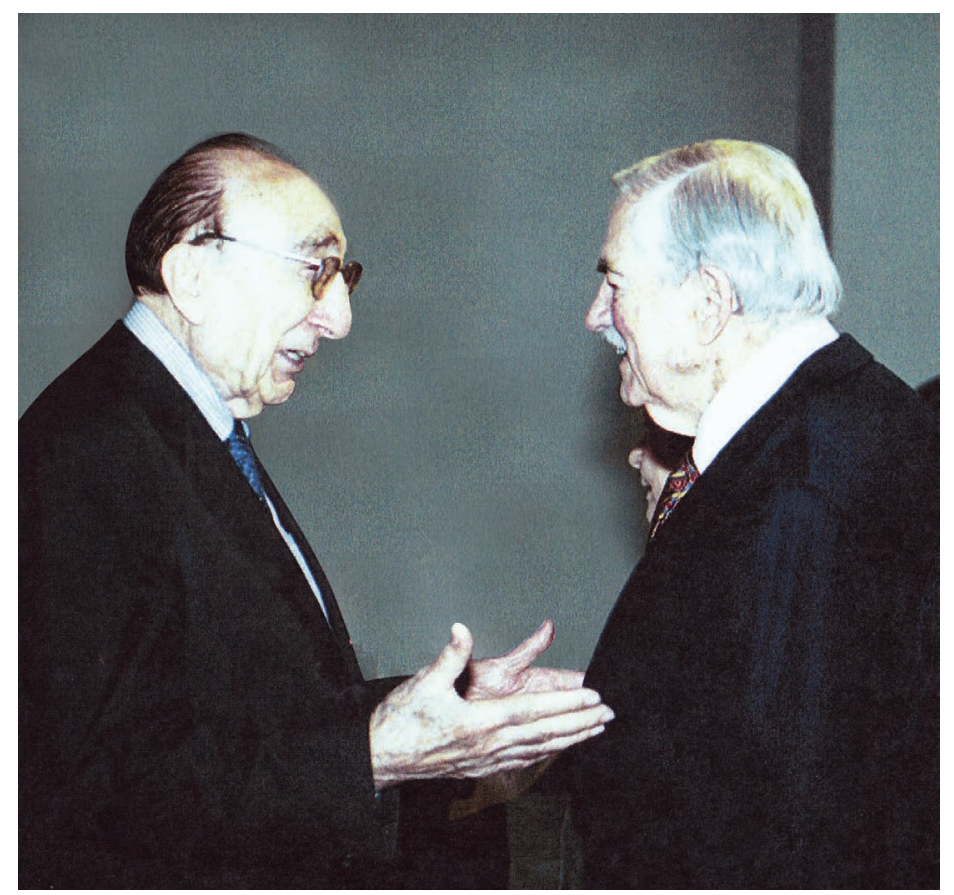

Photo 30. DeBakey with Don Chapman at dedication of the Houston Methodist DeBakey Heart \& Vascular Center, 2001.

Dr. Robert Roberts, our chairman of cardiology for 20 years, in the field of cardiovascular genetics; the contributions of Dr. Jim Young (Photo 29) — the first medical director of the Methodist Heart Transplant Program-and his successors, Drs. Guillermo Torre and Jeffry Estep, and of so many others to this very rich history.

Before closing, I must pay one last tribute to Don Chapman and Michael DeBakey. My closest friend and colleague for 40 years, Chapman was honored for his lifetime achievements by receiving the George P. McGovern Compleat Physician Award in 2006, one year before he died on May 3, 2007, at age 90 (Photo 30). DeBakey made an extraordinary recovery from his dissecting aneurysm surgery performed by Noon in 2006. He was able to enjoy the opening of the DeBakey Library and Museum at Baylor in October of 2006 and then receive the Congressional Medal of Honor from President George W. Bush on April 23, 2008 (Photo 31).

But on July 1, 2008, after visits from both Noon and Gotto and without permission from anyone, he died suddenly and unexpectedly at home, 2 months shy of his 100th birthday. His subsequent memorial service at the Co-Cathedral of the Sacred Heart in downtown Houston was the most memorable I have ever attended. I was privileged to serve as one of his pall bearers. He was the most remarkable man I have ever known, bar none (refer to Online Video 6). Who else do you know who has ever read an encyclopedia from cover to cover?
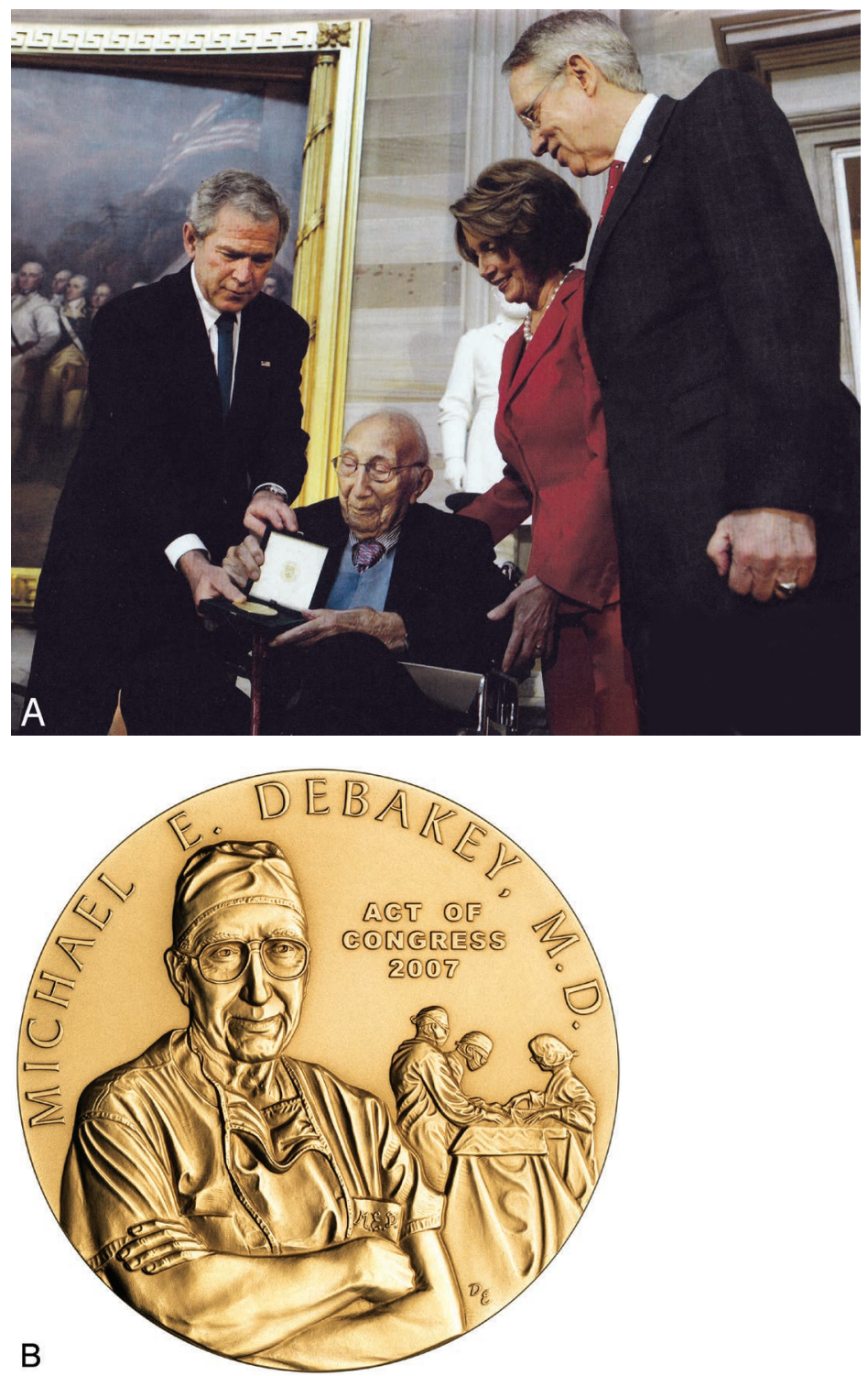

Photo 31. (A) DeBakey receives Congressional Gold Medal from President George W. Bush and Speaker of the House Nancy Pelosi on April 23, 2008; (B) Congressional Gold Medal. (Photos by Chris Greenberg)

On a final note, history is really important! The culture of this fine institution will better flourish if the rich history of people and events of all disciplines are made known to all those who follow.

Houston Hearts: A History of Cardiovascular Surgery and Medicine at Houston Methodist DeBakey Heart E Vascular Center is available in the Houston Methodist Hospital gift shop and online through both Amazon and Kindle. 